\title{
Functional traits and plasticity linked to seedlings' performance under shade and drought in Mediterranean woody species
}

\author{
David SÁncheZ-Gómez ${ }^{1 *}$, Miguel A. ZaVala ${ }^{1,2}$, Fernando VAlladARES $^{3,4}$ \\ ${ }^{1}$ Instituto Nacional de Investigación y Tecnología Agraria y Alimentaria, Carretera Coruña Km. 7,5, 28040 Madrid, Spain \\ ${ }^{2}$ Departamento de Ecología, Edificio de Ciencias, Universidad de Alcalá. Alcalá de Henares, 28871 Madrid, Spain \\ ${ }^{3}$ Instituto de Recursos Naturales, Centro de Ciencias Medioambientales C.S.I.C. Serrano 115 dpdo, 28006 Madrid, Spain \\ ${ }^{4}$ Departamento de Biología y Geología, Escuela Superior de Ciencias Experimentales y Tecnológicas, Universidad Rey Juan Carlos, \\ c/ Tulipán s/n, 28933 Móstoles, Spain
}

(Received 27 March 2007; Version revised 4 July 2007; accepted 24 August 2007)

\begin{abstract}
Interspecific differences in morphology, biomass allocation and phenotypic plasticity along an experimental irradiance gradient and two contrasting water regimes were studied for eight Mediterranean woody species at the seedling stage; a critical demographic stage in Mediterranean plant communities. We tested whether species variation in these traits can explain previously reported interspecific differences in performance under shade and drought. Four irradiance levels (1\%, 6\%, 20\% and 100\% of full sunlight) and two water regimes (well watered and water-stressed conditions) in 6\% and $100 \%$ irradiance levels were established. Quercus species exhibited the largest seeds, the highest total dry mass and also the highest root-shoot ratio, but their leaf mass fraction (LMF) and leaf area ratio (LAR) were low. Pistacia terebinthus, and Arbutus unedo exhibited the opposite traits. From those traits that correlated with seed size only LAR resulted significantly linked to survival in deep shade. None of the traits studied correlated with survival under water-stressed conditions. Overall phenotypic plasticity was negatively correlated with survival in deep shade but no correlation was found with survival under water-stressed conditions. Our results highlight the importance of low LAR and low phenotypic plasticity as potential determinants of enhanced performance under shade during the very early seedling stages of Mediterranean woody species. Low LAR was also positively correlated with seed size and consequently, its relationship with enhanced performance under shade might change at later life stages of the plant when seed reserves are no longer available.
\end{abstract}

conservative resource-use strategy / leaf area ratio / root-shoot ratio / seed size / specific leaf area

Résumé - Traits fonctionnels et plasticité en relation avec les performances de semis de ligneux méditerranéens sous ombrage et en situation de sécheresse. Les différences interspécifiques de morphologie, d'allocation de biomasse et de plasticité phénotypique ont été étudiées pour des semis de huit espèces ligneuses méditerranéennes sous un gradient d'ombrage et soumis à deux régimes d'alimentation hydrique. Le stade semis est un stade critique pour la démographie des communautés végétales méditerranéennes. Nous avons testé l'hypothèse que des différences dans ces traits pouvaient expliquer les différences inter-spécifiques de performances souvent décrites sous ombrage et sous sécheresse. Nous avons imposé quatre niveaux d'ombrage $(1 \%, 6 \%, 20 \%$ and $100 \%$ du rayonnement incident) et deux régimes hydriques (irrigation abondante et déficit hydrique pour les traitements $6 \%$ et $100 \%$ ). Les chênes présentaient les graines les plus grosses, la plus forte biomasse et également le rapport racine/parties aériennes le plus élevé, mais leurs rapports (biomasse foliaire/biomasse totale) et (surface foliaire/biomasse totale) (LAR) étaient faibles. Pistacia terebinthus, et Arbutus unedo présentaient des caractéristiques opposées. Parmi ces traits liés à la taille des graines, seul LAR était fortement corrélé à la survie sous ombre forte. Aucun des traits mesurés n'était corrélé à la survie sous sécheresse. Le degré de plasticité phénotypique était corrélé négativement avec la survie sous ombre forte, mais aucune corrélation n'a pu être détectée avec la survie sous sécheresse. Ces résultats soulignent l'importance d'un LAR faible et d'une faible plasticité phénotypique comme déterminants d'une survie sous fort ombrage pendant les tous premiers stades de développement des semis de ligneux méditerranéens. De faibles valeurs de LAR étaient également associées à de fortes biomasses initiales des graines; son effet sur la performance des semis à l'ombre risque de ce fait de disparaître lors des stades de développement ultérieurs quand les réserves des graines sont épuisées.

stratégie conservatrice d'utilisation des ressources / rapport surface foliaire / biomasse totale / rapport racine / parties aériennes / dimensions des graines / surface spécifique

\section{INTRODUCTION}

The development of a mechanistic plant ecology must be based on the identification of key mechanisms that summarize most of the complexity associated with more detailed explanations [40]. The identification of key functional traits related

* Corresponding author: david.sango@gmail.com to interspecific differences in plant performance under limiting resources seeks this objective [37,39].

The ecological significance of a suite of traits depends on the covariation among those traits [1] so it is essential to consider both correlated and independent traits when linking these traits to ecological strategies. According to the nichedifferentiation hypothesis, a species may specialize for one set of ecological factors, but this specialization may imply 
morphological and physiological compromises that restrict the competitive success of the species under different ecological conditions [19,32]. In the case of Mediterranean forests, where the co-occurrence of both light and water limitations are possible [3] plant ecological strategies and coexistence mechanisms may be largely explained by compromises associated to tolerance to drought, shade and recurrent disturbances $[52,53]$.

The study of traits related to shade tolerance and drought tolerance has received special attention since hypothesized interactive effects between shade and drought have important implications for the development of a mechanistic plant community ecology (see [33] for a revision). For example, interactive effects between shade and drought can result in a trade-off between shade and drought tolerance with shade tolerant species being more vulnerable to drought than lightdemanding species $[10,37]$. Following this idea shade tolerant species may be selected for a strong allocation to shoot at the expense of root allocation resulting in plants with efficient irradiance capture but more sensitive to drought [37]. Alternatively, several studies in tropical and cool-temperate seedlings suggest that shade tolerance may be associated with a conservative resource-use strategy $[24,31,47,48]$ rather than with a strategy of maximisation of the net rate of carbon gain under shade $[15,37]$. Accordingly, shade tolerance might be associated with traits such as low LAR, low SLA and in general with high allocation to below ground tissues. That suite of traits implies low leaf allocation and high storage allocation which in turn, has been linked to persistence during periods of non-positive carbon uptake balance [34] as occurs under shade. Also, that suite of traits may confer tolerance to drought through decreasing evaporating surface and increasing water uptake from the soil [26]. Thus, traits conferring shade and drought tolerance simultaneously might be possible within a conservative resource-use strategy [34].

Phenotypic plasticity is also a trait expected to influence shade and drought tolerance since the ability of changing the phenotype in response to the environment is a mechanism used by plants to optimize resource acquisition $[38,49]$. However the role that phenotypic plasticity plays on shade or drought tolerance remains unclear.

In a previous study we reported the existence of potential trade-offs in the response to irradiance and water availability for eight Mediterranean woody species, at the regeneration stage based on interspecific differences in survival and growth [36]. Specifically we found evidence for a trade-off between survival in the shade and relative growth rate (RGR) at high light, but no evidence for a trade-off between shade and drought tolerances. In this study, based on the same experiment, we aim to describe species-specific differences in biomass allocation, morphology and phenotypic plasticity as potential mechanisms underlying the interspecific differences found in seedlings' performance under shade and drought for these Mediterranean woody species. Our experiment targeted the very early species differences that may arise during the seedling stage. Specifically our objectives are based on the following hypotheses: (1) Species with enhanced performance under shade exhibit big seeds which, in turn, will produce seedlings with low leaf area ratio (LAR, defined as the ra- tio between leaf area and shoot dry weight), low specific leaf area (SLA, defined as the ratio between leaf area and leaf dry weight) and high allocation to above ground tissues rather than below ground tissues in agreement with a conservative resource-use strategy [31]. (2) Species with enhanced performance under drought will exhibit low SLA, low LAR, and in general, high allocation to below ground tissues rather than above ground tissues that contribute to decrease seedling evaporative demand [26]. (3) A low phenotypic plasticity may be linked to enhanced performance under shade and drought in agreement with the stress-tolerator syndrome $[9,18]$ and a conservative resource-use strategy [43].

\section{MATERIALS AND METHODS}

\subsection{Species description}

We selected seven woody species (Arbutus unedo L., Pistacia lentiscus L., Pistacia terebinthus L., Quercus coccifera L., Quercus faginea Lam., Quercus ilex subsp. ballota (Desf.) Samp. and Viburnum tinus L.) which are typical components of Mediterranean shrublands and forests. We also chose one cool-temperate species (Quercus robur L.) as an out-group species, which coexists with many of the above mentioned species at its southern distribution in many Mediterranean areas such as the Iberian Peninsula. The target species differ widely in seed size. For example, average seed size values for these species in the Iberian Peninsula are 3.636, 2.703, 2.667, 2.941, 0.023, 0.063, 0.002 and 0.065 for $Q$. robur, $Q$. faginea, $Q$. ilex, $Q$. coccifera, $P$. lentiscus, $P$. terebinthus, $A$. unedo and $V$. tinus respectively [8]. The studied species also differ in leaf habit ( $Q$. robur and $P$. terebinthus, deciduous, $Q$. faginea semi-deciduous, and $Q$. ilex, Q. coccifera, P. lentiscus, Arbutus unedo and Viburnum tinus evergreen). Species' performance under shade was studied in a previous paper [36] by means of their survivorship under deep shade (1\% of full sunlight). The species ranking for survival under deep shade was: ( $Q$. robur $=Q$. coccifera $)>Q$. faginea $\geqslant Q$. ilex $\geqslant P$. lentiscus $\geqslant V$. tinus $>(P$. terebinthus $=A$. unedo $)$. This ranking correlated significantly and positively with seed size [36]. Species' performance under drought was assessed by means of their survivorship in $100 \%$ of full sunlight $\times$ water-stressed treatment in this previous paper. The ranking for species' performance under drought was: $($ A. unedo $=V$. tinus $)$ $>P$. lentiscus $\geqslant Q$. robur $\geqslant(Q$. coccifera $=Q$. faginea $=Q$. ilex $)>$ $P$. terebinthus. This ranking was not correlated with seed size [36].

\subsection{Seed collection and germination}

Seeds were collected from characteristic Iberian localities in autumn 2001: $Q$. robur from south east Galicia, Q. faginea from Torrelaguna, Madrid, $Q$. ilex subsp ballota from Sierra Morena, Jaén, Q. coccifera from Cádiz, Pistacia lentiscus from Valencia, P. terebinthus from northern Andalucía, Arbutus unedo from Ávila and Viburnum tinus from Moratalla, Murcia. Seedlings were germinated from January to March 2002. In general, germination within in a species occurred at the same time ( \pm 5 days). Those seedlings that did not germinated within this time window were excluded from the experiment to minimize size effect at the beginning of the experiment. The rest of the seedlings were transplanted to forest multi-pot $\left(330 \mathrm{~cm}^{3}\right.$ each pot) containers and were grown from early-spring to 
autumn with each individual seedling occupying one single pot. Soil substrate ( $\mathrm{pH}$ 6.5) consisted of 3:1 volume mixture of peat Vriezenveen PP1 (Potgrond Vriezenveen B.V., Westerhaar, the Netherlands), and washed river sand. We also added $3 \mathrm{~kg} / \mathrm{m}^{3}$ of Guanumus Angibaud fertilizer (3-35-2 N-P-K, Angiplant, La Rochelle Cedex, France) and $2 \mathrm{~kg} / \mathrm{m}^{3}$ of Plantacote mix $4 \mathrm{M}$ fertilizer (15-10-15 NP-K, Aglukon Spezialdünger GMBH \& Co. KG, Dusseldorf, Germany).

\subsection{Description of the study site and experimental design}

The experiment was carried out at a commercial nursery (Viveros Barbol, Torremocha del Jarama, Madrid, Spain). The area was located at $40^{\circ} 50^{\prime} \mathrm{N}, 3^{\circ} 29^{\prime} \mathrm{W}$ and at $710 \mathrm{~m}$ a.s.1. Climate is continental Mediterranean with hot and dry summers and cold winters. Mean maximum and minimum temperature were $19.7{ }^{\circ} \mathrm{C}$ and $9.9^{\circ} \mathrm{C}$ respectively. Most annual rainfall $(372 \mathrm{~mm})$ is received during spring and fall (76-102 mm respectively, values are mean for the last 25 years [22]. Local air temperature and available photosynthetic photon flux density (PPFD) were registered every 5 min during the whole growing season with a data logger (HOBO model H08-00604, Onset, Pocasset, MA, USA) and external sensors cross-calibrated with a Li-Cor 190SA sensor (Li-Cor, Nebraska, USA). Mean daily PPFD over the summer was 41 moles $\mathrm{m}^{2}$ day $^{-1}$ referred to as full sunlight thereafter.

The experimental setting was based on a factorial design with two factors: irradiance availability, and species. Four irradiance levels (1, 6,20 and $100 \%$ of sunlight) were established by using layers of neutral shade cloth supported by metal frames. Air mean temperature during the experiment was similar $\left( \pm 1{ }^{\circ} \mathrm{C}\right)$ across different irradiance environments. The established irradiance gradient spans over the natural range of light availability found in Iberian forest understories, $20 \%$ being the most common shade under Mediterranean forest canopies and $6 \%$ of full sunlight being relatively frequent in humid and sub-humid temperate forests $[16,41]$. Levels around $1 \%$ of full sunlight represent really dark understories, which have been reported for Mediterranean forests [17].

Water availability was also included in the design of the experiment to test for the impact of drought on seedlings' responses in two of the four irradiance levels (i.e. $6 \%$ and $100 \%$ of sunlight). One hundred percent of sunlight level was chosen to induce the strongest drought effect as water shortage coupled with high irradiance intensity. Six percent of sunlight level was chosen to test the impact of drought in a deep but still relatively common shade level. We did not choose $1 \%$ of sunlight level not only because its rareness in Mediterranean environments but also because at extremely low irradiance levels, soil resource availability (water and nutrients) may only have a marginal impact in comparison to the impact exerted by the low irradiance level, particularly in shoot growth [5]. Twenty percent of sunlight level was not chosen either because for many species it is known not to be limiting but near to optimal light conditions [35,36]. Two watering levels (well watered and water-stressed levels) were established. Half of seedlings in each irradiance level were grown under well watered conditions and the other half were grown under waterstressed conditions. The irrigation system consisted of watering by sprinklers. The highest light levels were more frequently and more intensively watered than the lowest light levels to compensate for increasing evapotranspiration under increasing irradiance. We monitored soil volumetric water content (SVC) six times along the grow- ing season for a sub-sample within all the treatments (ca. $n=40$ for well watered treatments and $n=22$ for water-stressed treatments) and we registered the minimum value reached for each individual (i.e. measurements were taken prior to watering to describe minimum values between two watering events). SVC was recorded with a portable moisture measurement instrument based on TDR method, TRIMEFM (Imko micromodultechnik GMBH, Ettlingen, Germany), connected to a $\mathrm{P} 2$ probe. SVC values recorded for the two contrasting soil water regimes were $26.7 \pm 0.5$ and $7.3 \pm 0.5$ for well watered and waterstressed treatments respectively (mean and $95 \%$ confidence intervals for SVC, \%vol, are provided). These SVC values corresponded to $-0.0 \mathrm{MPa}$ and $-2.2 \mathrm{MPa}$ in terms of soil water potential for well watered and water-stressed treatments respectively (calculated using the filter-paper technique) [14]. A value of -2.2 MPa for soil water potential can be considered as a moderate to severe drought since shoot water potential at the turgor loss point for $Q$. faginea, $Q$. ilex and $Q$. coccifera are near $-3 \mathrm{MPa}$ [7].

A total of 64-88 healthy seedlings per irradiance level and species were used for the experiment. Seedlings were arranged along four blocks. These blocks were randomly distributed within each shade frame corresponding to each irradiance level. Two extra blocks of 22 seedlings per species were placed in the 6 and $100 \%$ of sunlight levels for the water-stressed treatments.

The experiment started in mid-June 2002 when all the seedlings were placed in their treatments and finished in mid-October 2002 with seedlings' harvest when seedlings were eight months old. Seedlings were sprayed with a fungicide solution (50\% Carbendazyme, Fungicida Polivalente, COMPO Agricultura SL, Barcelona, Spain) twice during the experiment in order to control fungal infections.

\subsection{Morphology and biomass allocation measurements}

After four months of growth in their respective irradiance $\times$ water availability treatments, a sample of 15-18 seedlings for each irradiance $\times$ water availability combination was harvested and fractioned into leaves, stems, and roots. Dry mass of each fraction was weighted (after a minimum of 3 days in an oven at $65 \pm 2{ }^{\circ} \mathrm{C}$ ) to estimate the following morphological and structural variables: total dry biomass $(\mathrm{g})$, root-shoot ratio $\left(\mathrm{g} \mathrm{g}^{-1}\right)$, leaf mass fraction (LMF, $\mathrm{kg} \mathrm{kg}^{-1}$ ), root mass fraction ( $\mathrm{RMF}, \mathrm{kg} \mathrm{kg}^{-1}$ ), and stem mass fraction (SMF, $\mathrm{kg} \mathrm{kg}^{-1}$ ). A sub-sample of 5-8 seedlings for each irradiance $\times$ water availability combination was taken for total leaf area $\left(\mathrm{cm}^{2}\right)$ assessment. All the leaves of each seedling were digitally scanned and leaf area was calculated with UTHSCSA Image Tool for windows v. 2.00 (University of Texas Heath Science Centre in San Antonio, USA). Also specific leaf area (SLA, $\mathrm{m}^{2} \mathrm{~kg}^{-1}$ ) and leaf area ratio (LAR, $\mathrm{m}^{2} \mathrm{~kg}^{-1}$ ) were estimated.

\subsection{Phenotypic plasticity and data analysis}

Both phenotypic plasticity in response to irradiance and phenotypic plasticity in response to water availability for every trait and all the traits together (overall plasticity) were estimated by means of the RDPI as defined by [45]. We estimated phenotypic plasticity in response to irradiance for the subset of seedlings submitted to well watered conditions and phenotypic plasticity in response to water availability for the subset of seedlings submitted to non-limiting irradiance (i.e. $100 \%$ of full sunlight). 
Table I. Phenotypic plasticity in response to irradiance for each variable and species and overall plasticity for both irradiance and water availability obtained with the RDPI index. The letter codes indicate homogeneous groups among species for each variable. The letter codes between brackets indicate homogeneous groups between overall plasticity in response to irradiance and overall plasticity in response to water availability (one-way ANOVA, Fisher LSD- test, $p<0.05$ ). The star before the name of the variable denotes overall significant species effect on the response variable. Qr : Q. robur, Qf : Q. faginea, Qi : Q. ilex, Qc : Q. coccifera, $\mathrm{Pl}:$. lentiscus, $\mathrm{Pt}:$ P. terebinthus, Au : A. unedo, Vt : V. tinus.

\begin{tabular}{|c|c|c|c|c|c|c|c|c|}
\hline Variables & Qr & Qf & Qi & Qc & $\mathrm{Pl}$ & $\mathrm{Pt}$ & $\mathrm{Au}$ & $\mathrm{Vt}$ \\
\hline * SLA $\left(\mathrm{m}^{2} \mathrm{~kg}^{-1}\right)$ & $0.07 \mathrm{~b}$ & $0.17 \mathrm{ab}$ & $0.09 \mathrm{ab}$ & $0.11 \mathrm{ab}$ & $0.15 \mathrm{ab}$ & $0.17 \mathrm{ab}$ & $0.13 \mathrm{ab}$ & $0.19 \mathrm{a}$ \\
\hline$* \operatorname{LAR}\left(\mathrm{m}^{2} \mathrm{~kg}^{-1}\right)$ & $0.17 \mathrm{~b}$ & $0.35 \mathrm{a}$ & $0.25 \mathrm{ab}$ & $0.20 \mathrm{ab}$ & $0.23 \mathrm{ab}$ & $0.21 \mathrm{ab}$ & $0.18 \mathrm{~b}$ & $0.12 b$ \\
\hline root/shoot ratio $\left(\mathrm{g} \mathrm{g}^{-1}\right)$ & $0.18 \mathrm{a}$ & $0.13 \mathrm{a}$ & $0.17 \mathrm{a}$ & $0.23 \mathrm{a}$ & $0.12 \mathrm{a}$ & $0.17 \mathrm{a}$ & $0.16 \mathrm{a}$ & $0.19 \mathrm{a}$ \\
\hline$* \operatorname{LMF}\left(\mathrm{kg} \mathrm{kg}^{-1}\right)$ & $0.13 \mathrm{ab}$ & $0.10 \mathrm{ab}$ & $0.16 \mathrm{a}$ & $0.15 \mathrm{a}$ & $0.08 \mathrm{ab}$ & $0.05 \mathrm{~b}$ & $0.04 \mathrm{~b}$ & $0.08 \mathrm{ab}$ \\
\hline * RMF $\left(\mathrm{kg} \mathrm{kg}^{-1}\right)$ & $0.08 \mathrm{ab}$ & $0.05 \mathrm{~b}$ & $0.13 \mathrm{a}$ & $0.12 \mathrm{a}$ & $0.10 \mathrm{ab}$ & $0.09 \mathrm{ab}$ & $0.10 \mathrm{ab}$ & $0.08 \mathrm{ab}$ \\
\hline * $\operatorname{SMF}\left(\mathrm{kg} \mathrm{kg}^{-1}\right)$ & $0.07 \mathrm{ab}$ & $0.08 \mathrm{ab}$ & $0.05 \mathrm{~b}$ & $0.09 \mathrm{ab}$ & $0.12 \mathrm{a}$ & $0.07 \mathrm{ab}$ & $0.08 \mathrm{ab}$ & $0.10 \mathrm{ab}$ \\
\hline $\begin{array}{l}\text { * Overall plasticity } \\
\text { in response } \\
\text { to irradiance }\end{array}$ & $0.12 \mathrm{~b}(\mathrm{a})$ & $0.18 \mathrm{abc}(\mathrm{a})$ & $0.15 \mathrm{bc}(\mathrm{a})$ & $0.16 a b c(a)$ & $0.22 \mathrm{a}(\mathrm{a})$ & $0.20 \mathrm{ab}(\mathrm{a})$ & $0.18 \mathrm{ab}(\mathrm{a})$ & $0.13 \mathrm{bc}(\mathrm{a})$ \\
\hline $\begin{array}{l}\text { * Overall plasticity } \\
\text { in response to } \\
\text { water availability }\end{array}$ & $0.11 \mathrm{ab}(\mathrm{a})$ & $0.09 \mathrm{abc}(\mathrm{b})$ & $0.12 \mathrm{a}(\mathrm{a})$ & $0.12 \mathrm{a}(\mathrm{a})$ & $0.07 \mathrm{c}(\mathrm{b})$ & $0.07 \mathrm{c}(\mathrm{b})$ & $0.08 \mathrm{bc}(\mathrm{b})$ & $0.06 \mathrm{c}(\mathrm{b})$ \\
\hline
\end{tabular}

Differences in morphology and biomass allocation patterns across factors (species, irradiance and water availability) were analysed with ANOVA. Fisher LSD-test was used for post-hoc analysis. In a similar way differences in plasticity in response to irradiance and in response to water availability across species were analysed with ANOVA. Prior to ANOVA analysis, data were checked for normality and homogeneity of variances, and were log-transformed when necessary to correct deviations from these assumptions [50]. Spearman rank correlations were used to test for specific relations among performance under shade or drought and the traits studied here (phenotypic plasticity included). Performance under shade and drought were estimated as survival in $1 \%$ irradiance level under well watered conditions and survival in $100 \%$ irradiance level under water-stressed conditions respectively (obtained from survival data in the same experiment analysed in a previous study [36]. All the statistical analysis was performed using STATISTICA v. 6.0 (Statsoft Inc., Tulsa, OK, USA).

\section{RESULTS}

\subsection{Species-specific differences across the irradiance gradient}

Total dry mass decreased with decreasing irradiance for all the species but $V$. tinus. The species ranking in total dry mass was $Q$. robur $>Q$. ilex $>Q$. coccifera $>Q$. faginea $>(P$. lentiscus $=A$. unedo $=P$. terebinthus $)>V$. tinus. This ranking did not change substantially across the irradiance gradient (but see Supplementary Tab. 1 for details, available on the journal web site at http://www.afs-journal.org/).

Irradiance had a significant effect on total leaf area for Q. faginea, P. lentiscus, P. terebinthus and A. unedo but had no effect for the rest of Quercus species and V. tinus. The total leaf area ranking changed from deep shade (i.e. $1 \%$ irradiance level) to high light (i.e. $100 \%$ irradiance level), so that $Q u e r$ cus species exhibited the highest total leaf area in deep shade while A. unedo and P. terebinthus equalled or even surpassed them in high light (Supplementary Tab. 1).

SLA decreased with increasing irradiance for $Q$. ilex, $P$. lentiscus, $P$. terebinthus and A. unedo. Irradiance did not have effect on the SLA for the rest of species $(p=0.0032$, ANOVA $p$-value for species/irradiance interaction). Species differed in SLA clearer as irradiance increased. In high light, $Q$. robur exhibited the highest SLA followed by $Q$. faginea, $P$. terebinthus, A. unedo, V. tinus and $Q$. coccifera with intermediate values and $Q$. ilex and P. lentiscus with the lowest values. In deep shade P. terebinthus, V. tinus, Quercus robur and $A$. unedo exhibited the highest SLA values followed in decreasing order by $Q$. coccifera, $P$. lentiscus, $Q$. faginea and Q. ilex (Supplementary Tab. 1).

Irradiance had a significant effect on LAR for all the species studied but $Q$. faginea and $V$. tinus. In general, increasing irradiance decreased LAR (Supplementary Tab. 1). In deep shade, A. unedo, Pistacia species and $V$. tinus had higher LAR than Quercus species. A similar pattern was found in high light (Supplementary Tab. 1).

Root-shoot ratio decreased with increasing shade for $Q$. robur, $Q$. ilex, $Q$. coccifera and $P$. lentiscus species but this effect was not significant for the rest of species. $Q$. faginea was the species with the highest root-shoot ratio values in most of the irradiance levels studied (Supplementary Tab. 1).

Irradiance had a significant effect on LMF for all the species but $Q$. faginea, $P$. terebinthus and A. unedo. In general, LMF decreased with increasing irradiance. However, V. tinus experienced the lowest LMF in deep shade. Quercus species exhibited the lowest LMF in both deep shade and high light but differences among species were clearer in high light (Supplementary Tab. 1). The ranking of species in high light was: $A$. unedo $=V$. tinus $>P$. lentiscus $>P$. terebinthus $>(Q$. ilex $=$ $Q$. coccifera $)>(Q$. robur $=Q$. faginea $)$. 
RMF increased with increasing irradiance for all the species but $Q$. faginea, A. unedo and V. tinus. For these species irradiance did not have a significant effect on RMF. In general Quercus species and $V$. tinus exhibited the highest RMF values in deep shade however V. tinus with A. unedo, and Pistacia species together exhibited lower values than Quercus species in high light. (Supplementary Tab. 1).

SMF decreased with increasing irradiance for $Q$. coccifera. For $P$. lentiscus the reverse was true. Irradiance did not have a significant effect on SMF for the rest of species. Q. robur exhibited the highest SMF values across the irradiance gradient and $Q$. coccifera the lowest values (Supplementary Tab. 1).

A general biomass allocation pattern was identified regardless of the water treatment. This pattern was that $Q$. faginea and $Q$. robur had the highest RMF and the lowest LMF followed in RMF decreasing order by $Q$. coccifera, $Q$. ilex, P. terebinthus, V. tinus, P. lentiscus and A. unedo. The last three species were those that exhibited the highest LMF regardless of the irradiance $\times$ water combination (see Fig. 1 and Supplementary Tab. 1). LAR resulted significantly and negatively correlated with enhanced performance under shade (Fig. 2).

\subsection{Impact of drought and species-specific differences}

The impact of drought was stronger in $100 \%$ than in $6 \%$ of full sunlight, impacting on more species in the former (Supplementary Tab. 2, available on the journal web site at http://www.afs-journal.org/). The ranking of species for the studied variables exhibited minor changes between well watered and water-stressed conditions (Supplementary Tab. 2).

In $6 \%$ of full sunlight, drought decreased total dry mass for Q. robur. Drought had no impact though on total leaf area in this irradiance level. In $6 \%$ of full sunlight, SLA values were decreased by drought for $Q$. faginea but not drought effect was found for the rest of species. The effect on LAR was again slight, increasing the LAR values only for $Q$. robur and $A$. unedo. Drought had no impact on root-shoot ratio for any of the species in $6 \%$ of full sunlight. Drought increased the LMF and decreased the SMF for $A$. unedo. It decreased the RMF and increased the SMF for $Q$. robur. Drought also increased the SMF for $Q$. coccifera in this irradiance level (Supplementary Tab. 2).

In $100 \%$ of full sunlight, drought decreased the total dry mass for all the species but $V$. tinus. It decreased the total leaf area for $Q$. faginea and P. lentiscus. However, it had still little impact on SLA and LAR, increasing the SLA for $Q$. robur and the LAR for $Q$. ilex. Drought decreased the root-shoot ration for $Q$. robur, $Q$. ilex, $Q$. coccifera and A. unedo. It decreased LMF for $Q$. ilex and A. unedo but increased it for $V$. tinus. Drought decreased RMF for $Q$. robur, $Q$. ilex, $Q$. coccifera and A. unedo exerting no effect on the other species. Drought also increased SMF for Q. robur and Q. coccifera (Supplementary Tab. 2).

None of the traits studied were significantly correlated with seedlings' performance under drought, only total dry mass exhibited a trend towards the higher the total dry mass the lower performance under drought (Spearman $R=-0.690$, $p=0.057$, Fig. 3). Seed size correlated significantly and positively with absolute growth, root-shoot ratio, and RMF while negatively with LAR, and LMF (Spearman rank correlation, $p<0.05$ ) for both $1 \%$ of full sunlight $\times$ well watered treatment and $100 \%$ of full sunlight $\times$ water-stressed treatment.

Discussion of species-specific traits that may confer enhanced performance under drought will be based on results from $100 \%$ of full sunlight $\times$ water-stressed treatment given both that the impact of drought was stronger in $100 \%$ than in $6 \%$ of full sunlight and that identification of particular traits involved in enhanced performance under drought should be done under non-limiting conditions for all resources but water.

\subsection{Phenotypic plasticity}

Species significantly differed in phenotypic plasticity in response to irradiance for all the variables studied but root-shoot ratio. They also differed in overall plasticity in response to both irradiance and water availability (Supplementary Tab. 1). The ranking of species for phenotypic plasticity in response to irradiance changed with the variable considered. In general, Pistacia species exhibited the highest phenotypic plasticity for overall plasticity in response to irradiance, while Quercus species experienced higher phenotypic plasticity than Pistacia species, A. unedo and V. tinus for overall plasticity in response to water availability (Supplementary Tab. 1). Overall plasticity in response to irradiance was higher than overall plasticity in response to water availability for all the species. However, this result was not significant for $Q$. robur, Q. ilex and Q. coccifera (Supplementary Tab. 1). A negative relationship was found between overall phenotypic plasticity in response to irradiance and enhanced performance under shade (Spearman $R=-0.465, p=0.007$ ). However no relationship was found between overall phenotypic plasticity in response to water availability and enhanced performance under drought (Spearman $R=-0.361, p=0.379$ ).

\section{DISCUSSION}

\subsection{Traits associated with enhanced performance under shade and drought}

Species-specific differences in biomass allocation patterns and morphology are thought to underlie across-species variation in shade tolerance [31] but also in drought tolerance [26]. For instance high below-ground mass fractions or low SLA can reduce the demand for water or, in general, for growth resources [34]. In our study, Quercus species exhibited higher total dry mass and lower LAR values than the rest of species across all the irradiance and water treatments. Quercus species and V. tinus also exhibited the highest root-shoot ratio values in deep shade that agreed with high RMF and low LMF. Pistacia species and A. unedo exhibited the opposite pattern (i.e. low root-shoot ratio and RMF but high LMF). These interspecific differences in the studied suite of traits appeared to be linked 


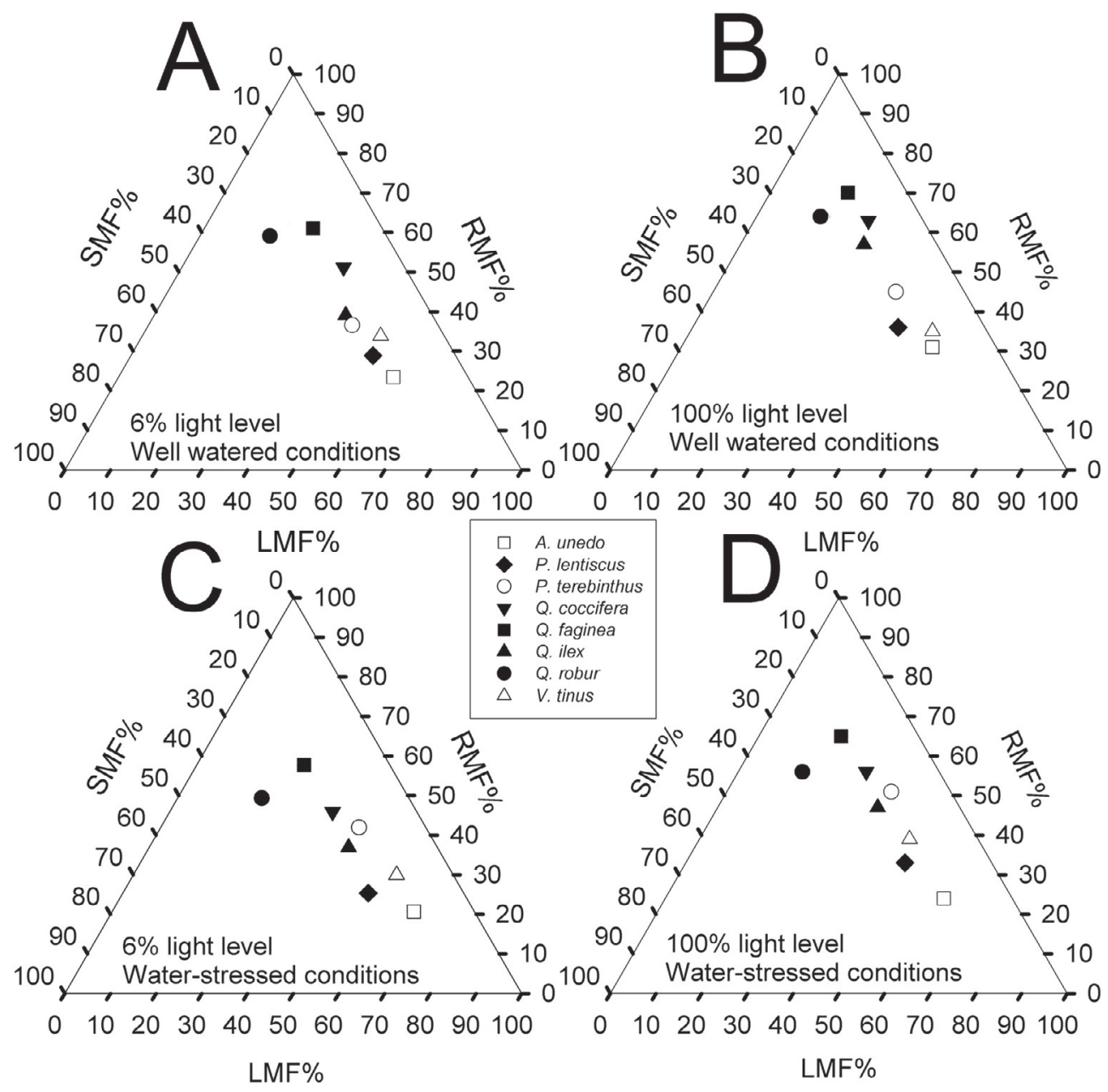

Figure 1. Ternary plot for species biomass allocation patterns (SMF, LMF, RMF accounting for stem, leaf and root mass fractions respectively) in both well watered (A, B) and water-stressed conditions (C, D) under 6\% of full sunlight (A, C) and under $100 \%$ of full sunlight (B, D). Ticks' angles indicate the plot orientation for each axis.

in turn to interspecific differences in seed size. Significant evidence was found for linkage between seed size, LAR, rootshoot ratio, RMF and LMF. From those traits which correlated with seed size, only LAR was significantly correlated with enhanced performance under shade. Thus, LAR was the only trait that explained the well accepted linkage between seed size and enhanced performance under shade [20, 21]. Low LAR values exhibited by species with enhanced performance under shade also agrees with evidence from previous studies which suggest a conservative resource-use strategy underlying shade tolerance $[35,47,48]$. A low LAR implies low leaf allocation and high storage allocation (i.e. structural biomass: stem and thick roots) which has been linked to persistence during periods of non-positive carbon uptake balance (i.e. in the shade) [34].

SLA is an important trait that can explain interspecific differences in seedlings' performance. In particular, SLA is frequently found to be the trait that better explains interspecific differences in seedlings' RGR $[2,13,30]$. However, this trait was not linked to enhanced performance under shade in this study. The same has been found in a field experiment for saplings of rain forest tree species [29]. Shade tolerant species do not necessarily grow faster than intolerant species under low irradiance [24, 25], but rather they survive better under such conditions. Thus, we hypothesize that traits directly linked to RGR as SLA, are not good predictors of seedlings' performance under shade at least during the very early stages.

Drought tolerance can be achieved by increasing the below ground biomass allocation and by decreasing the shoot evaporating surface [26]. Under drought, Quercus species exhibited higher RMF and lower LMF and LAR than the rest of species, and also a higher total dry mass, which has been linked also to drought tolerance [11]. However, these species did not exhibit the best performance under drought in or study. In turn, $V$. tinus and $A$. unedo, which exhibited the lowest total dry mass under drought, had relatively higher performance under these conditions. This counter-intuitive result could be explained by phylogenetic constraints on allometry and allocation patterns with species with poor performance under drought exhibiting inherent patterns of high allocation to roots 


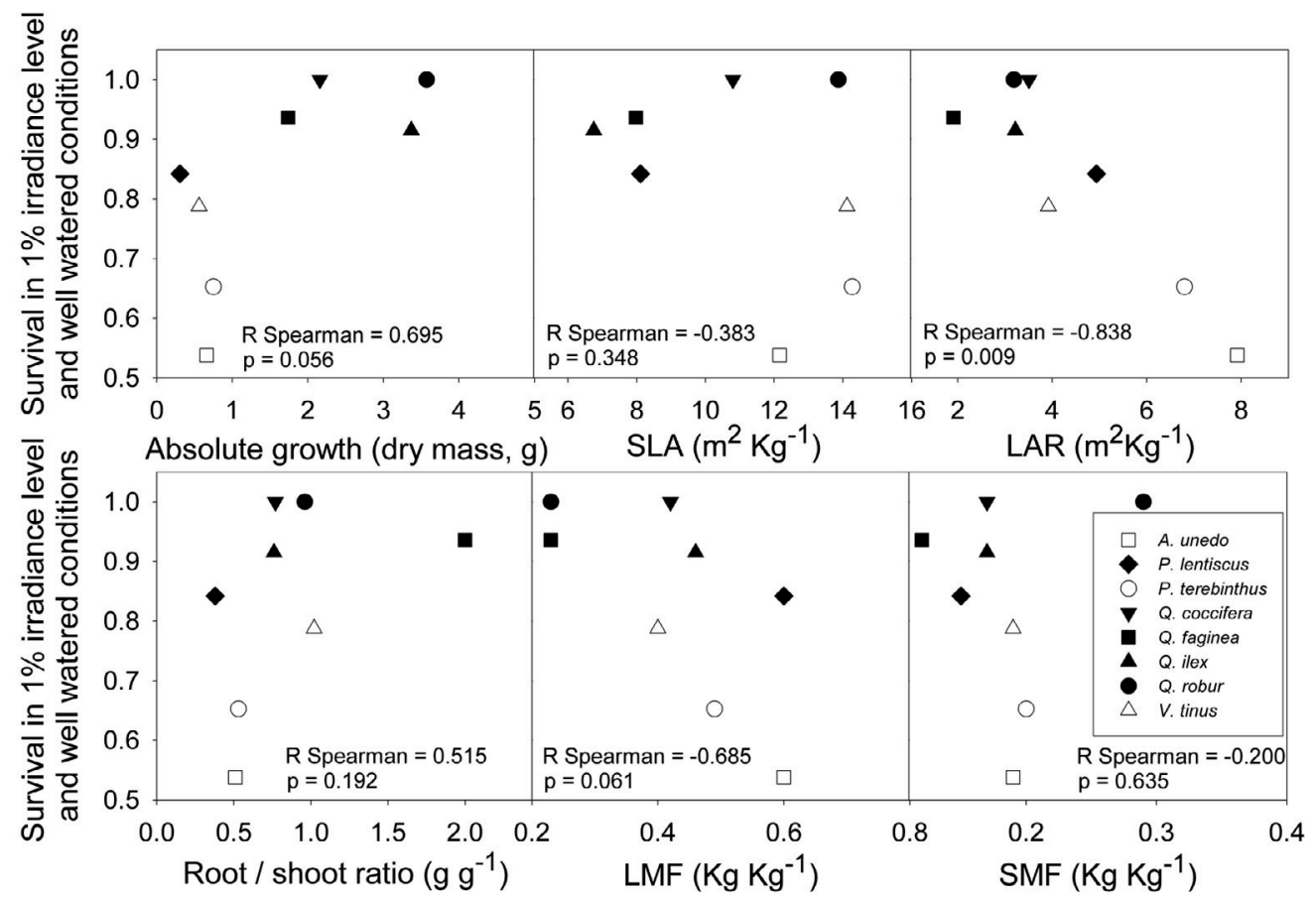

Figure 2. Spearman correlations between survival in $1 \%$ of full sunlight under well watered conditions and different variables studied. Total leaf area and root mass fraction (RMF) were excluded to avoid redundancy with absolute growth and root/shoot ratio respectively, variables which they were correlated with.

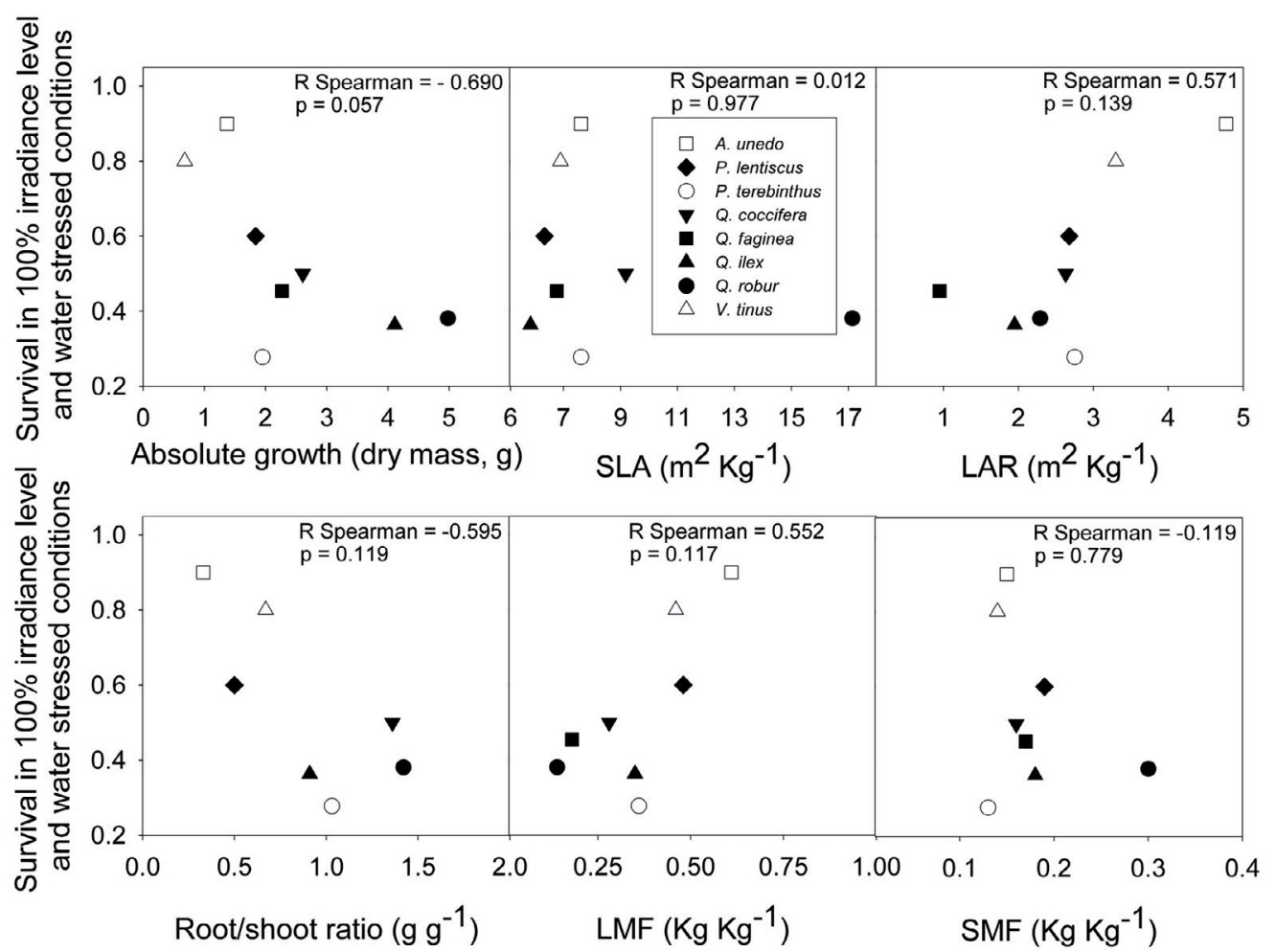

Figure 3. Spearman correlations between survival in $100 \%$ of full sunlight under water-stressed conditions and different variables studied. Total leaf area and root mass fraction (RMF) were excluded to avoid redundancy with absolute growth and root/shoot ratio respectively, variables which they were correlated with. 
and low allocation to leaf area. Morphological traits might be more influenced by phylogeny and thus less flexible in their response to drought than physiological traits [44], particularly at the seedling stage. Another explanation might be that even though a large seedlings may offer some advantages under drought [12], a large size also implies high total leaf area in absolute terms. This may contribute to a stronger evaporative demand than smaller seedlings, rapid depletion of soil water content and consequently a lower survival rates under drought $[4,51]$. In addition, $P$. terebinthus which exhibited the lowest performance under drought, had low total dry mass plus high LMF which together results in a water inefficient allocation pattern.

\subsection{The role of phenotypic plasticity}

Optimal foraging theory for essential resources predicts that a plant should modulate its morphology and adjust its physiology in order to be equally limited by all essential resources [39]. Given a genotype, phenotypic plasticity is the feature that permits such modulations and adjustments. Thus not only the intrinsic suite of traits of species but also its phenotypic plasticity in response to irradiance and water availability may contribute to explain interspecific differences in seedlings' performance under drought or shade. Our results partially support such an idea since phenotypic plasticity in response to irradiance was negatively linked to enhanced performances under shade in agreement with the stress-tolerator syndrome [9, 18] and a conservative resource-use strategy [43]. However, phenotypic plasticity in response to water availability was not linked to enhanced performance under drought. Although species differed in phenotypic plasticity, they exhibited lower values and a much narrower range of values when compared with tropical species $(0.3-0.4$ and $0.3-0.7$ for the species studied here and species studied in [46] respectively using the same phenotypic plasticity index for comparisons). Given the high unpredictability of irradiance, water and nutrient availability in Mediterranean communities, Mediterranean woody species might have converged to a low degree of phenotypic plasticity and high canalization (sensu [23] as an adaptive process [42]. Despite the relatively low phenotypic plasticity of Mediterranean woody species, across-species variation in phenotypic plasticity still correlated with interspecific differences in seedlings' performance under drought.

The species rankings for the values of the studied traits under drought did not change substantially with respect to the rankings exhibited under well watered conditions and neither did the biomass allocation patterns (Supplementary Tab. 2 and Fig. 1). Both, the low plasticity exhibited by all the species in response to water availability and the lack of relationship between phenotypic plasticity and performance under drought suggest that the traits exhibited under drought may depend more on intrinsic species features than in species capability to modulation of these characteristics. Thus, our results suggest that for Mediterranean woody species, seedlings' performance under shade but not under drought is linked to interspecific differences in phenotypic plasticity.

\subsection{Concluding remarks}

Our results highlight the role of key traits such as LAR and phenotypic plasticity as potential determinants of interspecific differences in seedlings' performance under shade in woody Mediterranean seedlings. Contrary to some previous studies, performance under shade was maximized by an increased allocation to storage and not to leaves. In agreement with the stress tolerance syndrome, not only an increased allocation to storage but also a reduced phenotypic plasticity conferred enhanced seedling' performance under limiting conditions, at least regarding light availability. However, studies with seedlings have obvious limitations. Species allocation patterns change with ontogeny but also the way plants respond to light in early stages depends on the rate of ontogenetic change [27]. Although germination and seedling establishment are major demographic bottlenecks in Mediterranean ecosystems, further studies on saplings, juveniles and adults are required to get a better understanding of the mechanisms underlying interspecific differences in performance along environmental gradients. Our study has focused on an ecologically crucial life stage of woody plants in Mediterranean ecosystems and consequently conclusions derived from our results have a number of limitations: (i) changes over the ontogeny regarding tolerance to shade and drought, plasticity and functional traits may lead to contrasting findings with the very same species studied at later life stages; (ii) the confounding effect of seed size and plant size on performance and under gradients of irradiance and water restricts our findings to a particular ecological setting (i.e. interspecific differences seedlings' performance during the first year) with reduced mechanistic insights on traits conferring shade and drought tolerances for other ecological settings.

Acknowledgements: We thank Daniela Brites and Iker Dobarro for their qualified help with the plant measurements, nursery Viveros Barbol for technical assistance and Silvia Matesanz, and David Tena for logistic support. Financial support was provided by Spanish Ministry for Education and Science (grants REN2000-0163-P4, ECOFIARB, RASINV, CGL2004-04884-C02-02/BOS, and PLASTOFOR, AGL2004-00536/FOR) S-G was supported by a grant of the Spanish MECD (FPU fellowship, AP2001-0193). Interactions among scientists from CSIC and Universidad de Alcalá were facilitated by scientific meetings hosted by the forest research network GLOBIMED (www.globimed.net).

\section{REFERENCES}

[1] Ackerly D., Functional strategies of chaparral shrubs in relation to seasonal water deficit and disturbance, Ecol. Monogr. 74 (2004) $25-44$.

[2] Antúnez I., Retamosa E.C., Villar R., Relative growth rate in phylogenetically related deciduous and evergreen woody species, Oecologia 128 (2001) 172-180.

[3] Aschman H., Distribution and peculiarity of Mediterranean ecosystems, in: di Castri F., Mooney H.A. (Eds.), Mediterranean type ecosystems: origin and structure, Springer-Verlag, Berlin, 1973, pp. 11-19.

[4] Broncano M.J., Riba M., Retana J., Seed germination and seedling performance of two Mediterranean tree species, holm oak (Quercus 
ilex) and Aleppo pine (Pinus halepensis): a multifactor experimental approach, Plant Ecol. 1 (1998) 17-26.

[5] Canham C.D., Berkowitz A.R., Kelly V.R., Lovett G.M., Ollinger S.V., Schnurr J., Biomass allocation and multiple resource limitation in tree seedlings, Can. J. For. Res. 26 (1996) 1521-1530.

[6] Castro J., Zamora R., Hódar J.A., Gómez J.M., Seedling establishment of a boreal tree species (Pinus sylvestris) at its southernmost distribution limit: consequences of being in a marginal, Mediterranean habitat, J. Ecol. 92 (2004) 266-277.

[7] Castro-Diez P., Navarro J., Pintado A., Sancho L.G., Maestro M., Interactive effects of shade and irrigation on the performance of seedlings of three Mediterranean Quercus species, Tree Physiol. 26 (2006) 389-400.

[8] Catalán Bachiller G., Semillas de árboles y arbustos forestales, ICONA, Madrid, 1993.

[9] Chapin F.S., Autumn K., Pugnaire F.I., Evolution of suites of traits in response to environmental-stress, Am. Nat. 142S (1993) S78S92.

[10] Cochard H., Lemoine D., Dreyer E., The effects of acclimation to sunlight on the xylem vulnerability to embolism in Fagus sylvatica L., Plant Cell Environ. 22 (1999) 101-108.

[11] Coomes D.A., Grubb P.J., Impacts of root competition in forests and woodlands: A theoretical framework and review of experiments, Ecol. Monogr. 70 (2000) 171-207.

[12] Coomes D.A., Grubb P.J., Colonization, tolerance, competition and seed-size variation within functional groups, Trends Ecol. Evol. 18 (2003) 283-291.

[13] Cornelissen J.H.C., Castro Diez P., Hunt R., Seedling growth, allocation and leaf attributes in a wide range of woody plant species and types, J. Ecol. 84 (1996) 755-765.

[14] Deka R.N., Wairiu M., Mtakwa P.W., Mullins C.E., Veenendaal E.M., Townend J., Use and accuracy of the filter-paper technique for measurement of soil matric potential, Eur. J. Soil Sci. 46 (1995) 233-238.

[15] Givnish T.J., Adaptation to sun and shade: a whole-plant perspective, Aust. J. Plant Physiol. 15 (1988) 63-92.

[16] Gómez J.M., Valladares F., Puerta-Piñero C., Differences between structural and functional heterogeneity caused by seed dispersal, Funct. Ecol. 18 (2004) 787-792.

[17] Gratani L., Canopy structure, vertical radiation profile and photosynthetic function in a Quercus ilex evergreen forest, Photosynthetica 33 (1997) 139-149.

[18] Grime J.P., Plant strategies, vegetation processes, and ecosystem properties, John Wiley \& Sons, Ltd, Chichester, GB, 2001.

[19] Grubb P.J., The maintenance of species-richness in plant communities: the importance of the regeneration niche, Biol. Rev. 52 (1977) 107-145.

[20] Grubb P.J., Metcalfe D.J., Adaptation and inertia in the Australian tropical lowland rain-forest flora: contradictory trends in intergeneric and intrageneric comparisons of seed size in relation to light demand, Funt. Ecol. 10 (1996) 512-520.

[21] Hewitt N., Seed size and shade-tolerance: a comparative analysis of North American temperate trees, Oecologia 114 (1998) 432-440.

[22] Instituto-Nacional-de-Meteorología, Calendario meteorológico 2002, Ministerio de Medio Ambiente, Madrid, 2002.

[23] Kawecki T.J., The evolution of genetic canalization under fluctuating selection, Evolution 54 (2000) 1-12.

[24] Kitajima K., Relative importance of photosynthetic traits and allocation patterns as correlates of seedling shade tolerance of 13 tropical trees, Oecologia 98 (1994) 419-428.
[25] Kobe R.K., Pacala S.W., Silander J.A.J., Juvenile tree survivorship as a component of shade tolerance, Ecol. Appl. 5 (1995) 517-532.

[26] Ludlow M.M., Strategies of response to water stress, in: Kreeb K.H., Richter H., Hinckley T.M. (Eds.), Structural and functional responses to environmental stresses, SPB Academic Publishing, The Hague, 1989, pp. 269-281.

[27] Niinemets Ü, The controversy over traits conferring shade-tolerance in trees: ontogenetic changes revisited, J. Ecol. 94 (2006) 464-470.

[28] Pigott C.D., Pigott S., Water as a determinant of the distribution of trees at the boundary of the Mediterranean zone, J. Ecol. 81 (1993) 557-566.

[29] Poorter L., Light-dependent changes in biomass allocation and their importance for growth of rain forest tree species, Funct. Ecol. 15 (2001) 113-123.

[30] Reich P.B., Walters M.B., Ellsworth D.S., Leaf life-span in relation to leaf, plant, and stand characteristics among diverse ecosystems, Ecol. Monogr. 62 (1992) 365-392.

[31] Reich P.B., Wright I.J., Cavender-Bares J., Craine M., Oleksyn J., Westoby M., Walters M.B., The evolution of plant functional variation: traits, spectra and strategies, Int. J. Plant Sci. 164 (2003) S143S164.

[32] Rickleffs R.E., Environmental heterogeneity and plant species diversity: A hypothesis, Am. Nat. 111 (1977) 376-381.

[33] Sack L., Grubb P.J., The combined impacts of deep shade and drought on the growth and biomass allocation of shade-tolerant woody seedlings, Oecologia 131 (2002) 175-185.

[34] Sack L., Grubb P.J., Marañón T., The functional morphology of juvenile plants tolerant of strong summer drought in shaded forest understories in southern Spain, Plant Ecol. 168 (2003) 139-163.

[35] Sánchez-Gómez D., Valladares F., Zavala M.A., Functional traits and plasticity in response to light in seedlings of four Iberian forest tree species, Tree Physiol. 26 (2006) 1425-1433.

[36] Sánchez-Gómez D., Valladares F., Zavala M.A., Performance of seedlings of Mediterranean woody species under experimental gradients of irradiance and water availability: trade-offs and evidence for niche differentiation, New Phytol. 170 (2006) 795-806.

[37] Smith T., Huston M., A theory of the spatial and temporal dynamics of plant communities, Vegetatio 83 (1989) 49-69.

[38] Sultan S.E., What has survived of Darwin's theory? Phenotypic plasticity and the Neo-Darwinian legacy, Evol.Trend Plant 6 (1992) $61-71$.

[39] Tilman D., Plant strategies and the dynamics and structure of plant communities, Princeton University Press, Princeton, New Jersey, USA, 1988.

[40] Tilman D., Constraints and tradeoffs: toward a predictive theory of competition and succession, Oikos 58 (1990) 3-15.

[41] Valladares F., Global change and radiation in Mediterranean forest ecosystems: a meeting point for ecology and management, in: Arianoutsou M., Papanastasis V. (Eds.), Ecology, conservation and sustainable managements of Mediterranean type ecosystems of the world, Millpress, Rotterdam, 2004, pp. 1-4.

[42] Valladares F., Balaguer L., Martínez-Ferri E., Pérez-Corona E., Manrique E., Plasticity, instability and canalization: is the phenotypic variation in seedlings of sclerophyll oaks consistent with the environmental unpredictability of Mediterranean ecosystems, New Phytol. 156 (2002) 457-467.

[43] Valladares F., Martinez-Ferri E., Balaguer L., Perez-Corona E., Manrique E., Low leaf-level response to light and nutrients in Mediterranean evergreen oaks: a conservative resource-use strategy?, New Phytol. 148 (2000) 79-91. 
[44] Valladares F., Sánchez-Gómez D., Ecophysiological traits associated with drought in Mediterranean tree seedlings: Individual responses versus interspecific trends in eleven species, Plant Biol. 8 (2006) 688-697.

[45] Valladares F., Sánchez-Gómez D., Zavala M.A., Quantitative estimation of phenotypic plasticity: bridging the gap between the evolutionary concept and its ecological applications, J. Ecol. 94 (2006) $1103-1116$.

[46] Valladares F., Wright S.J., Lasso E., Kitajima K., Pearcy R.W., Plastic phenotypic response to light of 16 congeneric shrubs from a Panamanian rainforest, Ecology 81 (2000) 1925-1936.

[47] Veneklaas E.J., Poorter L., Growth and carbon partitioning of tropical tree seedlings in contrasting light environments, in: Lambers $\mathrm{H}$., Poorter H., Van Vuuren M.M.I. (Eds.), Inherent variation in plant growth: physiological mechanisms and ecological consequences, Backhuys, Leiden, NL, 1998, pp. 337-361.
[48] Walters M.B., Reich P.B., Low-light carbon balance and shade tolerance in the seedlings of woody plants: do winter deciduous and broad-leaved evergreen species differ?, New Phytol. 143 (1999) $143-154$.

[49] West-Eberhard M.J., Phenotypic plasticity and the origins of diversity, Ann. Rev. Ecol. Syst. 20 (1989) 249-278.

[50] Zar J.H., Biostatistical analysis, Prentice Hall, New Jersey, 1999.

[51] Zavala M.A., Bravo de la Parra R., A mechanistic model of tree competition and facilitation for Mediterranean forests: Scaling from leaf physiology to stand dynamics, Ecol. Model. 188 (2005) 76-92.

[52] Zavala M.A., Espelta J.M., Retana J., Constraints and trade-offs in Mediterranean plant communities: the case of Holm oak-Aleppo pine forests, Bot. Rev. 66 (2000) 119-149.

[53] Zavala M.A., Zea G.E., Mechanisms maintaining biodiversity in Mediterranean pine-oak forests: insights from a spatial simulation model, Plant Ecol. 171 (2004) 197-207. 


\section{Online Material}


Table I. Mean and standard error for the variables studied across the four levels of irradiance considered (1, 6, 20 and 100\%) and for each species (Q. robur: Qr; Q. faginea: Qf; Q. ilex: Qi; Q. coccifera: Qc; P. lentiscus: Pl; P. terebinthus: Pt; A. unedo: Au; V. tinus: Vt). First letter code indicates differences between irradiance levels and the second (between braquets) indicates differences among species, one-way ANOVA, Fisher LSD-test, $p<0.05$. ANOVA analysis were performed with the log-transformed variables. A total of 15-18 seedlings per species and irradiance level combination were considered for all the variables but total leaf area, SLA, and LAR. For the latter $n=5-8$. The star before the species code indicate overall significant irradiance effect within the species (ANOVA main effects, $p<0.05$ ). Overall species effect was significant for all the variables $\times$ irradiance levels.

\begin{tabular}{|c|c|c|c|c|c|c|c|c|c|}
\hline \multirow[b]{2}{*}{ Variables } & & \multicolumn{2}{|c|}{$1 \%$} & \multicolumn{2}{|c|}{$6 \%$} & \multicolumn{2}{|c|}{$20 \%$} & \multicolumn{2}{|c|}{$100 \%$} \\
\hline & & Mean & s.e. & Mean & s.e & Mean & s.e. & Mean & s.e. \\
\hline Total dry mass & ${ }^{*} \mathrm{Qr}$ & 3.57 & $0.33 \mathrm{c}(\mathrm{a})$ & 5.48 & $0.45 \mathrm{~b}(\mathrm{a})$ & 7.80 & $0.56 \mathrm{a}(\mathrm{a})$ & 6.83 & $0.64 \mathrm{ab}(\mathrm{a})$ \\
\hline \multirow[t]{7}{*}{ (g) } & ${ }^{*} \mathrm{Qf}$ & 1.74 & $0.31 \mathrm{~b}((\mathrm{~b})$ & 2.48 & $0.27 \mathrm{~b}(\mathrm{c})$ & 3.96 & $0.41 \mathrm{a}(\mathrm{c})$ & 4.61 & $0.43 \mathrm{a}(\mathrm{bc})$ \\
\hline & ${ }^{*} \mathrm{Qi}$ & 3.37 & $0.21 \mathrm{c}(\mathrm{a})$ & 4.57 & $0.37 \mathrm{c}(\mathrm{b})$ & 5.77 & $0.52 \mathrm{~b}(\mathrm{~b})$ & 7.28 & $0.33 \mathrm{a}(\mathrm{a})$ \\
\hline & ${ }^{*} \mathrm{Qc}$ & 2.16 & $0.30 \mathrm{c}(\mathrm{b})$ & 2.24 & $0.32 \mathrm{c}(\mathrm{c})$ & 3.96 & $0.52 \mathrm{~b}(\mathrm{c})$ & 5.91 & $0.64 \mathrm{a}(\mathrm{ab})$ \\
\hline & $* \mathrm{Pl}$ & 0.31 & $0.05 \mathrm{c}(\mathrm{c})$ & 1.03 & $0.19 \mathrm{~b}(\mathrm{~d})$ & 3.11 & $0.40 \mathrm{a}(\mathrm{cd})$ & 3.63 & $0.38 \mathrm{a}(\mathrm{c})$ \\
\hline & $* \mathrm{Pt}$ & 0.75 & $0.17 \mathrm{c}(\mathrm{c})$ & 0.86 & $0.19 \mathrm{c}(\mathrm{d})$ & 2.45 & $0.38 \mathrm{~b}(\mathrm{~d})$ & 4.41 & $0.51 \mathrm{a}(\mathrm{c})$ \\
\hline & $* \mathrm{Au}$ & 0.66 & $0.12 \mathrm{c}(\mathrm{c})$ & 1.08 & $0.16 \mathrm{c}(\mathrm{d})$ & 2.62 & $0.44 \mathrm{~b}(\mathrm{~d})$ & 4.09 & $0.79 \mathrm{a}(\mathrm{c})$ \\
\hline & $\mathrm{Vt}$ & 0.56 & 0.07 (c) & 0.52 & 0.09 (d) & 0.87 & $0.12(\mathrm{e})$ & 1.01 & $0.25(\mathrm{~d})$ \\
\hline \multirow{8}{*}{$\begin{array}{l}\text { Total leaf area } \\
\left(\times 10^{-4} \mathrm{~m}^{2}\right)\end{array}$} & Qr & 136.20 & 32.12 (a) & 131.77 & 17.43 (a) & 152.12 & 29.67 (a) & 129.35 & $24.70(a b)$ \\
\hline & $* \mathrm{Qf}$ & 40.15 & $12.45 \mathrm{~b}(\mathrm{~cd})$ & 34.91 & $6.18 \mathrm{~b}(\mathrm{~b})$ & 111.70 & $30.22 \mathrm{a}(\mathrm{abc})$ & 52.10 & $10.88 \mathrm{~b}(\mathrm{~cd})$ \\
\hline & Qi & 117.42 & $21.23(\mathrm{ab})$ & 152.23 & 44.25 (a) & 102.38 & $12.18(\mathrm{abc})$ & 108.24 & $9.11(\mathrm{abc})$ \\
\hline & Qc & 90.00 & $21.13(\mathrm{~b})$ & 70.71 & $16.46(b)$ & 87.91 & $16.65(\mathrm{abc})$ & 116.82 & $31.18(\mathrm{abc})$ \\
\hline & $* \mathrm{Pl}$ & 17.39 & $1.57 \mathrm{~b}(\mathrm{~d})$ & 30.90 & $6.92 \mathrm{~b}(\mathrm{~b})$ & 83.81 & $14.87 \mathrm{a}(\mathrm{bc})$ & 81.98 & $8.98 \mathrm{a}(\mathrm{bc})$ \\
\hline & $* \mathrm{Pt}$ & 38.76 & $15.82 \mathrm{~b}(\mathrm{~cd})$ & 51.68 & $18.04 \mathrm{~b}(\mathrm{~b})$ & 120.22 & $23.08 \mathrm{a}(\mathrm{ab})$ & 133.20 & $16.02 \mathrm{a}(\mathrm{ab})$ \\
\hline & $* \mathrm{Au}$ & 51.01 & $6.12 \mathrm{c}(\mathrm{c})$ & 68.87 & $14.02 \mathrm{bc}(\mathrm{b})$ & 129.68 & $24.35 \mathrm{ab}(\mathrm{ab})$ & 162.42 & $33.31 \mathrm{a}(\mathrm{a})$ \\
\hline & $\mathrm{Vt}$ & 20.54 & $3.78(\mathrm{~cd})$ & 25.51 & $5.12(b)$ & 29.86 & $5.83(\mathrm{c})$ & 22.70 & $6.57(\mathrm{~d})$ \\
\hline \multirow{8}{*}{$\begin{array}{l}\text { SLA } \\
\left(\mathrm{m}^{2} \mathrm{~kg}^{-1}\right)\end{array}$} & Qr & 13.87 & $2.72(\mathrm{ab})$ & 16.27 & 0.98 (a) & 15.13 & 0.46 (a) & 12.86 & 1.20 (a) \\
\hline & Qf & 7.98 & $0.54(\mathrm{ab})$ & 12.62 & $2.11(\mathrm{bc})$ & 13.90 & 3.50 (a) & 8.28 & 0.69 (b) \\
\hline & $* \mathrm{Qi}$ & 6.75 & $0.45 \mathrm{ab}(\mathrm{b})$ & 6.88 & $0.37 \mathrm{a}(\mathrm{e})$ & 5.65 & $0.30 \mathrm{bc}(\mathrm{c})$ & 5.00 & $0.11 \mathrm{c}(\mathrm{c})$ \\
\hline & Qc & 10.80 & $3.18(a b)$ & 6.99 & $0.57(\mathrm{e})$ & 7.11 & $0.34(\mathrm{bc})$ & 7.00 & 1.05 (b) \\
\hline & $* \mathrm{Pl}$ & 8.11 & $0.74 \mathrm{a}(\mathrm{b})$ & 8.08 & $0.54 \mathrm{a}(\mathrm{de})$ & 6.28 & $0.91 \mathrm{ab}(\mathrm{c})$ & 4.86 & $0.21 \mathrm{~b}(\mathrm{c})$ \\
\hline & $* \mathrm{Pt}$ & 14.27 & $0.95 \mathrm{a}(\mathrm{ab})$ & 14.48 & $1.36 \mathrm{a}(\mathrm{ab})$ & 10.18 & $1.06 \mathrm{~b}(\mathrm{~b})$ & 8.06 & $0.39 \mathrm{~b}(\mathrm{~b})$ \\
\hline & $* \mathrm{Au}$ & 12.16 & $1.43 \mathrm{a}(\mathrm{ab})$ & 10.47 & $0.39 \mathrm{ab}(\mathrm{cd})$ & 9.29 & $0.27 \mathrm{bc}(\mathrm{b})$ & 7.55 & $0.48 \mathrm{c}(\mathrm{b})$ \\
\hline & $\mathrm{Vt}$ & 14.12 & 3.41 (a) & 11.09 & $0.62(\mathrm{c})$ & 8.15 & $0.48(\mathrm{bc})$ & 7.25 & $0.46(b)$ \\
\hline \multirow{8}{*}{$\begin{array}{l}\text { LAR } \\
\left(\mathrm{m}^{2} \mathrm{~kg}^{-1}\right)\end{array}$} & $* \mathrm{Qr}$ & 3.19 & $0.49 \mathrm{a}(\mathrm{cd})$ & 2.31 & $0.17 \mathrm{ab}(\mathrm{c})$ & 1.93 & $0.30 \mathrm{~b}(\mathrm{c})$ & 1.73 & $0.34 \mathrm{~b}(\mathrm{bc})$ \\
\hline & Qf & 1.91 & $0.22(\mathrm{~d})$ & 2.51 & $0.42(\mathrm{c})$ & 5.00 & $2.42(\mathrm{ab})$ & 1.22 & $0.12(\mathrm{c})$ \\
\hline & $* \mathrm{Qi}$ & 3.22 & $0.17 \mathrm{a}(\mathrm{cd})$ & 3.09 & $0.43 \mathrm{a}(\mathrm{bc})$ & 1.67 & $0.16 \mathrm{~b}(\mathrm{c})$ & 1.38 & $0.08 \mathrm{~b}(\mathrm{bc})$ \\
\hline & ${ }^{*} \mathrm{Qc}$ & 3.51 & $0.66 \mathrm{a}(\mathrm{cd})$ & 2.47 & $0.39 \mathrm{ab}(\mathrm{c})$ & 1.87 & $0.11 \mathrm{~b}(\mathrm{c})$ & 1.68 & $0.25 \mathrm{~b}(\mathrm{bc})$ \\
\hline & $* \mathrm{Pl}$ & 4.94 & $0.51 \mathrm{a}(\mathrm{bc})$ & 4.35 & $0.42 \mathrm{ab}(\mathrm{b})$ & 3.01 & $0.52 \mathrm{bc}(\mathrm{bc})$ & 2.14 & $0.06 \mathrm{c}(\mathrm{b})$ \\
\hline & $* \mathrm{Pt}$ & 6.80 & $0.77 \mathrm{a}(\mathrm{ab})$ & 7.00 & $0.75 \mathrm{a}(\mathrm{a})$ & 4.45 & $0.49 \mathrm{~b}(\mathrm{ab})$ & 3.44 & $0.25 \mathrm{~b}(\mathrm{a})$ \\
\hline & $* \mathrm{Au}$ & 7.92 & $1.04 \mathrm{a}(\mathrm{a})$ & 6.28 & $0.21 \mathrm{~b}(\mathrm{a})$ & 5.42 & $0.28 \mathrm{~b}(\mathrm{a})$ & 4.04 & $0.28 \mathrm{c}(\mathrm{a})$ \\
\hline & $\mathrm{Vt}$ & 3.92 & $0.81(\mathrm{c})$ & 5.88 & 0.66 (a) & 3.61 & $0.13(a b c)$ & 3.87 & 0.33 (a) \\
\hline \multirow{8}{*}{$\begin{array}{l}\text { root-shoot ratio } \\
\left(\mathrm{g} \mathrm{g}^{-1}\right)\end{array}$} & ${ }^{*} \mathrm{Qr}$ & 0.96 & $0.06 \mathrm{c}(\mathrm{b})$ & 1.61 & $0.19 \mathrm{ab}(\mathrm{a})$ & 1.56 & $0.09 \mathrm{~b}(\mathrm{a})$ & 2.02 & $0.20 \mathrm{a}(\mathrm{b})$ \\
\hline & Qf & 2.00 & 0.23 (a) & 1.63 & 0.15 (a) & 1.72 & 0.22 (a) & 2.59 & 0.31 (a) \\
\hline & $* \mathrm{Qi}$ & 0.76 & $0.16 \mathrm{~b}(\mathrm{bc})$ & 0.76 & $0.07 \mathrm{~b}(\mathrm{bcd})$ & 1.10 & $0.07 \mathrm{a}(\mathrm{b})$ & 1.34 & $0.06 \mathrm{a}(\mathrm{cd})$ \\
\hline & ${ }^{*} \mathrm{Qc}$ & 0.77 & $0.07 \mathrm{c}(\mathrm{bc})$ & 1.08 & $0.08 \mathrm{~b}(\mathrm{ab})$ & 1.59 & $0.12 \mathrm{a}(\mathrm{a})$ & 1.75 & $0.11 \mathrm{a}(\mathrm{bc})$ \\
\hline & $* \mathrm{Pl}$ & 0.38 & $0.05 \mathrm{~b}(\mathrm{c})$ & 0.41 & $0.02 \mathrm{~b}(\mathrm{~cd})$ & 0.38 & $0.06 \mathrm{~b}(\mathrm{c})$ & 0.59 & $0.05 \mathrm{a}(\mathrm{e})$ \\
\hline & $\mathrm{Pt}$ & 0.53 & $0.07(\mathrm{c})$ & 0.92 & $0.40(\mathrm{bc})$ & 0.57 & $0.04(\mathrm{~cd})$ & 0.87 & $0.11(\mathrm{de})$ \\
\hline & $\mathrm{Au}$ & 0.51 & $0.18(\mathrm{c})$ & 0.31 & 0.03 (d) & 0.59 & $0.14(\mathrm{~cd})$ & 0.47 & 0.05 (e) \\
\hline & $\mathrm{Vt}$ & 1.02 & $0.34(b)$ & 0.54 & 0.07 (bcd) & 0.79 & $0.05(\mathrm{bc})$ & 0.54 & $0.03(\mathrm{e})$ \\
\hline \multirow{8}{*}{$\begin{array}{l}\mathrm{LMF} \\
\left(\mathrm{kg} \mathrm{kg}^{-1}\right)\end{array}$} & $* \mathrm{Qr}$ & 0.23 & $0.02 \mathrm{a}(\mathrm{d})$ & 0.15 & $0.01 \mathrm{~b}(\mathrm{f})$ & 0.14 & $0.01 \mathrm{~b}(\mathrm{~d})$ & 0.14 & $0.01 \mathrm{~b}(\mathrm{e})$ \\
\hline & Qf & 0.23 & $0.02(\mathrm{~d})$ & 0.24 & 0.02 (e) & 0.25 & $0.04(\mathrm{c})$ & 0.17 & 0.02 (e) \\
\hline & $* \mathrm{Qi}$ & 0.46 & $0.02 \mathrm{a}(\mathrm{c})$ & 0.42 & $0.02 \mathrm{a}(\mathrm{c})$ & 0.30 & $0.01 \mathrm{~b}(\mathrm{c})$ & 0.27 & $0.01 \mathrm{~b}(\mathrm{~d})$ \\
\hline & $* \mathrm{Qc}$ & 0.42 & $0.03 \mathrm{a}(\mathrm{c})$ & 0.35 & $0.02 \mathrm{~b}(\mathrm{~d})$ & 0.27 & $0.02 \mathrm{c}(\mathrm{c})$ & 0.25 & $0.01 \mathrm{c}(\mathrm{d})$ \\
\hline & $* \mathrm{Pl}$ & 0.60 & $0.04 \mathrm{a}(\mathrm{a})$ & 0.53 & $0.02 \mathrm{ab}(\mathrm{b})$ & 0.49 & $0.02 \mathrm{~b}(\mathrm{ab})$ & 0.45 & $0.02 \mathrm{~b}(\mathrm{~b})$ \\
\hline & $\mathrm{Pt}$ & 0.49 & $0.03(\mathrm{bc})$ & 0.45 & $0.03(\mathrm{c})$ & 0.45 & 0.01 (b) & 0.40 & $0.02(\mathrm{c})$ \\
\hline & $\mathrm{Au}$ & 0.60 & $0.09(\mathrm{ab})$ & 0.60 & 0.02 (a) & 0.52 & 0.03 (a) & 0.55 & 0.02 (a) \\
\hline & $* \mathrm{Vt}$ & 0.40 & $0.07 \mathrm{~b}(\mathrm{c})$ & 0.52 & $0.03 \mathrm{a}(\mathrm{b})$ & 0.44 & $0.02 \mathrm{ab}(\mathrm{b})$ & 0.53 & $0.01 \mathrm{a}(\mathrm{a})$ \\
\hline
\end{tabular}


Table I. continued.

\begin{tabular}{|c|c|c|c|c|c|c|c|c|c|}
\hline \multirow[b]{2}{*}{ Variables } & & \multicolumn{2}{|c|}{$1 \%$} & \multicolumn{2}{|c|}{$6 \%$} & \multicolumn{2}{|c|}{$20 \%$} & \multicolumn{2}{|c|}{$100 \%$} \\
\hline & & Mean & s.e. & Mean & s.e & Mean & s.e. & Mean & s.e. \\
\hline RMF & $* \mathrm{Qr}$ & 0.47 & $0.02 \mathrm{~b}(\mathrm{~b})$ & 0.59 & $0.02 \mathrm{a}(\mathrm{a})$ & 0.60 & $0.01 \mathrm{a}(\mathrm{a})$ & 0.64 & $0.03 \mathrm{a}(\mathrm{ab})$ \\
\hline \multirow[t]{7}{*}{$\left(\mathrm{kg} \mathrm{kg}^{-1}\right)$} & Qf & 0.65 & 0.02 (a) & 0.61 & 0.02 (a) & 0.59 & $0.04(\mathrm{ab})$ & 0.70 & 0.03 (a) \\
\hline & *Qi & 0.37 & $0.02 \mathrm{~b}(\mathrm{~cd})$ & 0.39 & $0.04 \mathrm{~b}(\mathrm{c})$ & 0.52 & $0.02 \mathrm{a}(\mathrm{b})$ & 0.57 & $0.01 \mathrm{a}(\mathrm{c})$ \\
\hline & ${ }^{*} \mathrm{Qc}$ & 0.41 & $0.02 \mathrm{c}(\mathrm{bc}$ & 0.51 & $0.02 \mathrm{~b}(\mathrm{~b})$ & 0.60 & $0.02 \mathrm{a}(\mathrm{a})$ & 0.63 & $0.01 \mathrm{a}(\mathrm{bc})$ \\
\hline & $* \mathrm{Pl}$ & 0.25 & $0.03 \mathrm{~b}(\mathrm{e})$ & 0.29 & $0.01 \mathrm{~b}(\mathrm{de})$ & 0.27 & $0.03 \mathrm{~b}(\mathrm{e})$ & 0.36 & $0.02 \mathrm{a}(\mathrm{e})$ \\
\hline & $* \mathrm{Pt}$ & 0.32 & $0.02 \mathrm{~b}(\mathrm{de})$ & 0.37 & $0.04 \mathrm{~b}(\mathrm{~cd})$ & 0.36 & $0.01 \mathrm{~b}(\mathrm{~d})$ & 0.45 & $0.02 \mathrm{a}(\mathrm{d})$ \\
\hline & $\mathrm{Au}$ & 0.25 & $0.06(\mathrm{e})$ & 0.23 & $0.02(\mathrm{e})$ & 0.32 & 0.04 (de) & 0.31 & $0.02(\mathrm{e})$ \\
\hline & $\mathrm{Vt}$ & 0.43 & $0.06(\mathrm{bc})$ & 0.34 & $0.03(\mathrm{~cd})$ & 0.43 & $0.02(\mathrm{c})$ & 0.35 & 0.01 (e) \\
\hline \multirow{8}{*}{$\begin{array}{l}\text { SMF } \\
\left(\mathrm{kg} \mathrm{kg}^{-1}\right)\end{array}$} & Qr & 0.29 & 0.02 (a) & 0.26 & 0.02 (a) & 0.26 & 0.01 (a) & 0.22 & 0.02 (a) \\
\hline & Qf & 0.12 & $0.01(\mathrm{c})$ & 0.15 & 0.02 (bcd) & 0.16 & $0.01(\mathrm{~cd})$ & 0.13 & $0.01(\mathrm{~cd})$ \\
\hline & Qi & 0.17 & $0.01(\mathrm{bc})$ & 0.19 & 0.02 (b) & 0.18 & $0.01(b c)$ & 0.16 & $0.01(\mathrm{bc})$ \\
\hline & $* \mathrm{Qc}$ & 0.17 & $0.02 \mathrm{a}(\mathrm{bc})$ & 0.13 & $0.01 \mathrm{ab}(\mathrm{d})$ & 0.12 & $0.01 \mathrm{~b}(\mathrm{e})$ & 0.12 & $0.01 \mathrm{~b}(\mathrm{~d})$ \\
\hline & $* \mathrm{Pl}$ & 0.15 & $0.02 \mathrm{~b}(\mathrm{bc})$ & 0.18 & $0.02 \mathrm{~b}(\mathrm{bc})$ & 0.24 & $0.02 \mathrm{a}(\mathrm{a})$ & 0.19 & $0.01 \mathrm{~b}(\mathrm{ab})$ \\
\hline & $\mathrm{Pt}$ & 0.20 & 0.02 (b) & 0.19 & 0.01 (b) & 0.19 & 0.01 (b) & 0.15 & $0.01(\mathrm{bcd})$ \\
\hline & $\mathrm{Au}$ & 0.19 & $0.03(\mathrm{bc})$ & 0.16 & 0.01 (bcd) & 0.16 & $0.01(\mathrm{~cd})$ & 0.14 & $0.01(\mathrm{~cd})$ \\
\hline & $\mathrm{Vt}$ & 0.19 & 0.04 (bc) & 0.14 & $0.01(\mathrm{~cd})$ & 0.13 & 0.01 (de) & 0.13 & 0.01 (cd) \\
\hline
\end{tabular}


Table II. Mean and standard error for the variables studied across the four treatments of irradiance x water availability considered (6\% well watered, 6\% water-stressed, 100\% well watered and 100\% water-stressed) and for each species (Q. robur: Qr; Q. faginea: Qf; Q. ilex: Qi; Q. coccifera: Qc; P. lentiscus: Pl; P. terebinthus: Pt; A. unedo: Au; V. tinus: Vt). First letter code indicates differences between the irradiance $\times$ water availability treatments and the second (between braquets) indicates differences between species, one-way ANOVA, Fisher LSD-test, $p<0.05$. ANOVA analysis were performed with the log-transformed variables. A total of $15-18$ seedlings per species and irradiance $\times$ water availability level combination were considered for all the variables but total leaf area, SLA and LAR. For the latter $n=5-8$. Overall species effect was significant for all the variables $\times$ treatment levels.

\begin{tabular}{|c|c|c|c|c|c|c|c|c|c|}
\hline \multirow[b]{2}{*}{ Variables } & & \multicolumn{2}{|c|}{$6 \%$ well watered } & \multicolumn{2}{|c|}{$6 \%$ water-stressed } & \multicolumn{2}{|c|}{$100 \%$ well watered } & \multicolumn{2}{|c|}{$100 \%$ water-stressed } \\
\hline & & Mean & s.e. & Mean & s.e. & Mean & s.e. & Mean & s.e. \\
\hline Total dry mass & $\mathrm{Qr}$ & 5.48 & $0.45 \mathrm{a}$ & 3.05 & $0.20 \mathrm{~b}(\mathrm{~b})$ & 6.83 & $0.64 \mathrm{a}$ & 4.98 & $0.34 \mathrm{~b}(\mathrm{a})$ \\
\hline \multirow[t]{7}{*}{ (g) } & Qf & 2.48 & $0.27 \mathrm{a}$ & 2.29 & $0.16 \mathrm{a}(\mathrm{c})$ & 4.61 & $0.43 \mathrm{a}$ & 2.27 & $0.10 \mathrm{~b}(\mathrm{~cd})$ \\
\hline & Qi & 4.57 & $0.37 \mathrm{a}$ & 4.20 & $0.20 \mathrm{a}(\mathrm{a})$ & 7.28 & $0.33 \mathrm{a}$ & 4.11 & $0.43 \mathrm{~b}(\mathrm{~b})$ \\
\hline & Qc & 2.24 & $0.32 \mathrm{a}$ & 1.92 & $0.33 \mathrm{a}(\mathrm{c})$ & 5.91 & $0.64 \mathrm{a}$ & 2.61 & $0.24 \mathrm{~b}(\mathrm{c})$ \\
\hline & $\mathrm{Pl}$ & 1.03 & $0.19 \mathrm{a}$ & 1.06 & $0.15 \mathrm{a}(\mathrm{d})$ & 3.63 & $0.38 \mathrm{a}$ & 1.84 & $0.16 \mathrm{~b}(\mathrm{de})$ \\
\hline & $\mathrm{Pt}$ & 0.86 & $0.19 \mathrm{a}$ & 1.04 & $0.12 \mathrm{a}(\mathrm{d})$ & 4.41 & $0.51 \mathrm{a}$ & 1.95 & $0.69 \mathrm{~b}(\mathrm{cde})$ \\
\hline & $\mathrm{Au}$ & 1.08 & $0.16 \mathrm{a}$ & 1.03 & $0.13 \mathrm{a}(\mathrm{d})$ & 4.09 & $0.79 \mathrm{a}$ & 1.37 & $0.09 \mathrm{~b}(\mathrm{ef})$ \\
\hline & $\mathrm{Vt}$ & 0.52 & $0.09 \mathrm{a}$ & 0.50 & $0.06 \mathrm{a}(\mathrm{d})$ & 1.01 & $0.25 \mathrm{a}$ & 0.68 & $0.11 \mathrm{a}(\mathrm{f})$ \\
\hline \multirow{8}{*}{$\begin{array}{l}\text { Total leaf area } \\
\left(\mathrm{cm}^{2}\right)\end{array}$} & Qr & 131.77 & $17.43 \mathrm{a}$ & 122.14 & $27.63 \mathrm{a}(\mathrm{a})$ & 129.35 & $24.70 \mathrm{a}$ & 85.99 & $9.36 \mathrm{a}(\mathrm{a})$ \\
\hline & Qf & 34.91 & $6.18 \mathrm{a}$ & 46.09 & $6.55 \mathrm{a}(\mathrm{b})$ & 52.10 & $10.88 \mathrm{a}$ & 18.07 & $2.78 \mathrm{~b}(\mathrm{c})$ \\
\hline & Qi & 152.23 & $44.25 \mathrm{a}$ & 136.78 & $27.38 \mathrm{a}(\mathrm{a})$ & 108.24 & $9.11 \mathrm{a}$ & 71.02 & $12.96 \mathrm{a}(\mathrm{ab})$ \\
\hline & Qc & 70.71 & $16.46 \mathrm{a}$ & 58.44 & $20.53 \mathrm{a}(\mathrm{b})$ & 116.82 & $31.18 \mathrm{a}$ & 59.87 & $23.03 \mathrm{a}(\mathrm{ab})$ \\
\hline & $\mathrm{Pl}$ & 30.90 & $6.92 \mathrm{a}$ & 52.53 & $8.52 \mathrm{a}(\mathrm{b})$ & 81.98 & $8.98 \mathrm{a}$ & 45.34 & $5.71 \mathrm{~b}(\mathrm{bc})$ \\
\hline & $\mathrm{Pt}$ & 51.68 & $18.04 \mathrm{a}$ & 59.03 & $13.48 \mathrm{a}(\mathrm{b})$ & 133.20 & $16.02 \mathrm{a}$ & 69.58 & $6.87 \mathrm{a}(\mathrm{ab})$ \\
\hline & $\mathrm{Au}$ & 68.87 & $14.02 \mathrm{a}$ & 63.51 & $9.18 \mathrm{a}(\mathrm{b})$ & 162.42 & $33.31 \mathrm{a}$ & 63.81 & $5.13 \mathrm{a}(\mathrm{ab})$ \\
\hline & $\mathrm{Vt}$ & 25.51 & $5.12 \mathrm{a}$ & 32.71 & $7.62 \mathrm{a}(\mathrm{b})$ & 22.70 & $6.57 \mathrm{a}$ & 25.19 & $3.94 \mathrm{a}(\mathrm{c})$ \\
\hline \multirow{8}{*}{$\begin{array}{l}\text { SLA } \\
\left(\mathrm{m}^{2} \mathrm{~kg}^{-1}\right)\end{array}$} & Qr & 16.27 & $0.98 \mathrm{a}$ & 16.97 & $1.20 \mathrm{a}(\mathrm{a})$ & 12.86 & $1.20 \mathrm{~b}$ & 17.14 & $1.17 \mathrm{a}(\mathrm{a})$ \\
\hline & Qf & 12.62 & $2.11 \mathrm{a}$ & 8.35 & $0.50 \mathrm{~b}(\mathrm{~d})$ & 8.28 & $0.69 \mathrm{a}$ & 6.76 & $0.32 \mathrm{a}(\mathrm{bc})$ \\
\hline & Qi & 6.88 & $0.37 \mathrm{a}$ & 6.70 & $0.10 \mathrm{a}(\mathrm{d})$ & 5.00 & $0.11 \mathrm{a}$ & 5.84 & $0.61 \mathrm{a}(\mathrm{c})$ \\
\hline & $\mathrm{Qc}$ & 6.99 & $0.57 \mathrm{a}$ & 7.69 & $0.70 \mathrm{a}(\mathrm{d})$ & 7.00 & $1.05 \mathrm{a}$ & 9.18 & $2.14 \mathrm{a}(\mathrm{b})$ \\
\hline & $\mathrm{Pl}$ & 8.08 & $0.54 \mathrm{a}$ & 9.56 & $0.50 \mathrm{a}(\mathrm{cd})$ & 4.86 & $0.21 \mathrm{a}$ & 6.33 & $1.16 \mathrm{a}(\mathrm{c})$ \\
\hline & $\mathrm{Pt}$ & 14.48 & $1.36 \mathrm{a}$ & 13.08 & $0.52 \mathrm{a}(\mathrm{b})$ & 8.06 & $0.39 \mathrm{a}$ & 7.61 & $0.26 \mathrm{a}(\mathrm{bc})$ \\
\hline & $\mathrm{Au}$ & 10.47 & $0.39 \mathrm{a}$ & 11.23 & $0.61 \mathrm{a}(\mathrm{bc})$ & 7.55 & $0.48 \mathrm{a}$ & 7.61 & $0.21 \mathrm{a}(\mathrm{bc})$ \\
\hline & $\mathrm{Vt}$ & 11.09 & $0.62 \mathrm{a}$ & 9.69 & $0.62 \mathrm{a}(\mathrm{cd})$ & 7.25 & $0.46 \mathrm{a}$ & 6.89 & $0.19 \mathrm{a}(\mathrm{bc})$ \\
\hline LAR & Qr & 2.31 & $0.17 \mathrm{~b}$ & 3.49 & $0.63 \mathrm{a}(\mathrm{cd})$ & 1.73 & $0.34 \mathrm{a}$ & 2.29 & $0.36 \mathrm{a}(\mathrm{bc})$ \\
\hline \multirow[t]{7}{*}{$\left(\mathrm{m}^{2} \mathrm{~kg}^{-1}\right)$} & Qf & 2.51 & $0.42 \mathrm{a}$ & 1.90 & $0.15 \mathrm{a}(\mathrm{e})$ & 1.22 & $0.12 \mathrm{a}$ & 0.95 & $0.11 \mathrm{a}(\mathrm{d})$ \\
\hline & Qi & 3.09 & $0.43 \mathrm{a}$ & 2.77 & $0.70 \mathrm{a}(\mathrm{cde})$ & 1.38 & $0.08 \mathrm{~b}$ & 1.95 & $0.18 \mathrm{a}(\mathrm{cd})$ \\
\hline & Qc & 2.47 & $0.39 \mathrm{a}$ & 2.97 & $0.39 \mathrm{a}(\mathrm{de})$ & 1.68 & $0.25 \mathrm{a}$ & 2.63 & $0.96 \mathrm{a}(\mathrm{bc})$ \\
\hline & $\mathrm{Pl}$ & 4.35 & $0.42 \mathrm{a}$ & 4.76 & $0.76 \mathrm{a}(\mathrm{bc})$ & 2.14 & $0.06 \mathrm{a}$ & 2.68 & $0.32 \mathrm{a}(\mathrm{bc})$ \\
\hline & $\mathrm{Pt}$ & 7.00 & $0.75 \mathrm{a}$ & 5.11 & $0.74 \mathrm{a}(\mathrm{b})$ & 3.44 & $0.25 \mathrm{a}$ & 2.75 & $0.18 \mathrm{a}(\mathrm{bc})$ \\
\hline & $\mathrm{Au}$ & 6.28 & $0.21 \mathrm{~b}$ & 7.42 & $0.42 \mathrm{a}(\mathrm{a})$ & 4.04 & $0.28 \mathrm{a}$ & 4.77 & $0.13 \mathrm{a}(\mathrm{a})$ \\
\hline & $\mathrm{Vt}$ & 5.88 & $0.66 \mathrm{a}$ & 5.65 & $0.44 \mathrm{a}(\mathrm{b})$ & 3.87 & $0.33 \mathrm{a}$ & 3.30 & $0.31 \mathrm{a}(\mathrm{b})$ \\
\hline \multirow{8}{*}{$\begin{array}{l}\text { root-shoot ratio } \\
\left(\mathrm{g} \mathrm{g}^{-1}\right)\end{array}$} & Qr & 1.61 & $0.19 \mathrm{a}$ & 1.11 & $0.14 \mathrm{~b}(\mathrm{~b})$ & 2.02 & $0.20 \mathrm{a}$ & 1.42 & $0.15 \mathrm{~b}(\mathrm{~b})$ \\
\hline & Qf & 1.63 & $0.15 \mathrm{a}$ & 1.46 & $0.12 \mathrm{a}(\mathrm{a})$ & 2.59 & $0.31 \mathrm{a}$ & 2.06 & $0.17 \mathrm{a}(\mathrm{a})$ \\
\hline & Qi & 0.76 & $0.07 \mathrm{a}$ & 0.71 & $0.11 \mathrm{a}(\mathrm{cd})$ & 1.34 & $0.06 \mathrm{a}$ & 0.91 & $0.08 \mathrm{~b}(\mathrm{c})$ \\
\hline & Qc & 1.08 & $0.08 \mathrm{a}$ & 0.91 & $0.11 \mathrm{a}(\mathrm{bc})$ & 1.75 & $0.11 \mathrm{a}$ & 1.36 & $0.10 \mathrm{~b}(\mathrm{~b})$ \\
\hline & $\mathrm{Pl}$ & 0.41 & $0.02 \mathrm{a}$ & 0.49 & $0.21 \mathrm{a}(\mathrm{de})$ & 0.59 & $0.05 \mathrm{a}$ & 0.50 & $0.04 \mathrm{a}(\mathrm{cd})$ \\
\hline & $\mathrm{Pt}$ & 0.92 & $0.40 \mathrm{a}$ & 0.81 & $0.15 \mathrm{a}(\mathrm{bcd})$ & 0.87 & $0.11 \mathrm{a}$ & 1.03 & $0.03 \mathrm{a}(\mathrm{bc})$ \\
\hline & $\mathrm{Au}$ & 0.31 & $0.03 \mathrm{a}$ & 0.27 & $0.02 \mathrm{a}(\mathrm{e})$ & 0.47 & $0.05 \mathrm{a}$ & 0.33 & $0.04 \mathrm{~b}(\mathrm{~d})$ \\
\hline & $\mathrm{Vt}$ & 0.54 & $0.07 \mathrm{a}$ & 0.44 & $0.04 \mathrm{a}(\mathrm{de})$ & 0.54 & $0.03 \mathrm{a}$ & 0.67 & $0.07 \mathrm{a}(\mathrm{cd})$ \\
\hline \multirow{8}{*}{$\begin{array}{l}\mathrm{LMF} \\
\left(\mathrm{kg} \mathrm{kg}^{-1}\right)\end{array}$} & Qr & 0.15 & $0.01 \mathrm{a}$ & 0.18 & $0.02 \mathrm{a}(\mathrm{e})$ & 0.14 & $0.01 \mathrm{a}$ & 0.14 & $0.01 \mathrm{a}(\mathrm{f})$ \\
\hline & Qf & 0.24 & $0.02 \mathrm{a}$ & 0.24 & $0.01 \mathrm{a}(\mathrm{e})$ & 0.17 & $0.02 \mathrm{a}$ & 0.18 & $0.01 \mathrm{a}(\mathrm{e})$ \\
\hline & Qi & 0.42 & $0.02 \mathrm{a}$ & 0.44 & $0.02 \mathrm{a}(\mathrm{c})$ & 0.27 & $0.01 \mathrm{~b}$ & 0.35 & $0.01 \mathrm{a}(\mathrm{c})$ \\
\hline & Qc & 0.35 & $0.02 \mathrm{a}$ & 0.36 & $0.03 \mathrm{a}(\mathrm{d})$ & 0.25 & $0.01 \mathrm{a}$ & 0.28 & $0.02 \mathrm{a}(\mathrm{d})$ \\
\hline & $\mathrm{Pl}$ & 0.53 & $0.02 \mathrm{a}$ & 0.54 & $0.03 \mathrm{a}(\mathrm{b})$ & 0.45 & $0.02 \mathrm{a}$ & 0.48 & $0.02 \mathrm{a}(\mathrm{b})$ \\
\hline & $\mathrm{Pt}$ & 0.45 & $0.03 \mathrm{a}$ & 0.43 & $0.03 \mathrm{a}(\mathrm{c})$ & 0.40 & $0.02 \mathrm{a}$ & 0.36 & $0.01 \mathrm{a}(\mathrm{c})$ \\
\hline & $\mathrm{Au}$ & 0.60 & $0.02 \mathrm{~b}$ & 0.66 & $0.01 \mathrm{a}(\mathrm{a})$ & 0.55 & $0.02 \mathrm{~b}$ & 0.61 & $0.02 \mathrm{a}(\mathrm{a})$ \\
\hline & $\mathrm{Vt}$ & 0.52 & $0.03 \mathrm{a}$ & 0.58 & $0.02 \mathrm{a}(\mathrm{b})$ & 0.53 & $0.01 \mathrm{a}$ & 0.46 & $0.03 \mathrm{~b}(\mathrm{~b})$ \\
\hline
\end{tabular}


Table II. continued.

\begin{tabular}{|c|c|c|c|c|c|c|c|c|c|}
\hline \multirow[b]{2}{*}{ Variables } & & \multicolumn{2}{|c|}{$6 \%$ well watered } & \multicolumn{2}{|c|}{$6 \%$ water-stressed } & \multicolumn{2}{|c|}{$100 \%$ well watered } & \multicolumn{2}{|c|}{$100 \%$ water-stressed } \\
\hline & & Mean & s.e. & Mean & s.e. & Mean & s.e. & Mean & s.e. \\
\hline \multirow{8}{*}{$\begin{array}{l}\mathrm{RMF} \\
\left(\mathrm{kg} \mathrm{kg}^{-1}\right)\end{array}$} & Qr & 0.59 & $0.02 \mathrm{a}$ & 0.49 & $0.02 \mathrm{~b}(\mathrm{~b})$ & 0.64 & $0.03 \mathrm{a}$ & 0.56 & $0.03 \mathrm{~b}(\mathrm{~b})$ \\
\hline & Qf & 0.61 & $0.02 \mathrm{a}$ & 0.58 & $0.02 \mathrm{a}(\mathrm{a})$ & 0.70 & $0.03 \mathrm{a}$ & 0.65 & $0.02 \mathrm{a}(\mathrm{a})$ \\
\hline & Qi & 0.39 & $0.04 \mathrm{a}$ & 0.37 & $0.02 \mathrm{a}(\mathrm{cd})$ & 0.57 & $0.01 \mathrm{a}$ & 0.47 & $0.02 \mathrm{~b}(\mathrm{c})$ \\
\hline & Qc & 0.51 & $0.02 \mathrm{a}$ & 0.46 & $0.03 \mathrm{a}(\mathrm{b})$ & 0.63 & $0.01 \mathrm{a}$ & 0.56 & $0.02 \mathrm{~b}(\mathrm{~b})$ \\
\hline & $\mathrm{Pl}$ & 0.29 & $0.01 \mathrm{a}$ & 0.25 & $0.04 \mathrm{a}(\mathrm{ef})$ & 0.36 & $0.02 \mathrm{a}$ & 0.33 & $0.02 \mathrm{a}(\mathrm{d})$ \\
\hline & $\mathrm{Pt}$ & 0.37 & $0.04 \mathrm{a}$ & 0.42 & $0.04 \mathrm{a}(\mathrm{bc})$ & 0.45 & $0.02 \mathrm{a}$ & 0.51 & $0.01 \mathrm{a}(\mathrm{bc})$ \\
\hline & $\mathrm{Au}$ & 0.23 & $0.02 \mathrm{a}$ & 0.21 & $0.01 \mathrm{a}(\mathrm{f})$ & 0.31 & $0.02 \mathrm{a}$ & 0.24 & $0.02 \mathrm{~b}(\mathrm{e})$ \\
\hline & $\mathrm{Vt}$ & 0.34 & $0.03 \mathrm{a}$ & 0.30 & $0.02 \mathrm{a}(\mathrm{de})$ & 0.35 & $0.01 \mathrm{a}$ & 0.39 & $0.03 \mathrm{a}(\mathrm{d})$ \\
\hline \multirow{8}{*}{$\begin{array}{l}\text { SMF } \\
\left(\mathrm{kg} \mathrm{kg}^{-1}\right)\end{array}$} & Qr & 0.26 & $0.02 \mathrm{~b}$ & 0.32 & $0.02 \mathrm{a}(\mathrm{a})$ & 0.22 & $0.02 \mathrm{~b}$ & 0.30 & $0.03 \mathrm{a}(\mathrm{a})$ \\
\hline & Qf & 0.15 & $0.02 \mathrm{a}$ & 0.19 & $0.01 \mathrm{a}(\mathrm{bc})$ & 0.13 & $0.01 \mathrm{a}$ & 0.17 & $0.01 \mathrm{a}(\mathrm{b})$ \\
\hline & Qi & 0.19 & $0.02 \mathrm{a}$ & 0.19 & $0.01 \mathrm{a}(\mathrm{b})$ & 0.16 & $0.01 \mathrm{a}$ & 0.18 & $0.01 \mathrm{a}(\mathrm{b})$ \\
\hline & Qc & 0.13 & $0.01 \mathrm{~b}$ & 0.18 & $0.01 \mathrm{a}(\mathrm{bc})$ & 0.12 & $0.01 \mathrm{~b}$ & 0.16 & $0.01 \mathrm{a}(\mathrm{b})$ \\
\hline & $\mathrm{Pl}$ & 0.18 & $0.02 \mathrm{a}$ & 0.21 & $0.02 \mathrm{a}(\mathrm{b})$ & 0.19 & $0.01 \mathrm{a}$ & 0.19 & $0.02 \mathrm{a}(\mathrm{b})$ \\
\hline & $\mathrm{Pt}$ & 0.19 & $0.01 \mathrm{a}$ & 0.15 & $0.02 \mathrm{a}(\mathrm{cd})$ & 0.15 & $0.01 \mathrm{a}$ & 0.13 & $0.02 \mathrm{a}(\mathrm{b})$ \\
\hline & $\mathrm{Au}$ & 0.16 & $0.01 \mathrm{a}$ & 0.13 & $0.01 \mathrm{~b}(\mathrm{~d})$ & 0.14 & $0.01 \mathrm{a}$ & 0.15 & $0.01 \mathrm{a}(\mathrm{b})$ \\
\hline & $\mathrm{Vt}$ & 0.14 & $0.01 \mathrm{a}$ & 0.12 & $0.01 \mathrm{a}(\mathrm{d})$ & 0.13 & $0.01 \mathrm{a}$ & 0.14 & $0.01 \mathrm{a}(\mathrm{b})$ \\
\hline
\end{tabular}

